\title{
The Effects of Drive and Reward upon Concept Formation in Schizophrenia
}

Donald Edward Fuhrmann

Loyola University Chicago

Follow this and additional works at: https://ecommons.luc.edu/luc_diss

Part of the Psychology Commons

\section{Recommended Citation}

Fuhrmann, Donald Edward, "The Effects of Drive and Reward upon Concept Formation in Schizophrenia" (1967). Dissertations. 939.

https://ecommons.luc.edu/luc_diss/939

This Dissertation is brought to you for free and open access by the Theses and Dissertations at Loyola eCommons. It has been accepted for inclusion in Dissertations by an authorized administrator of Loyola eCommons. For more information, please contact ecommons@luc.edu. (c) (i) $\Theta \Theta$

This work is licensed under a Creative Commons Attribution-Noncommercial-No Derivative Works 3.0 License. Copyright @ 1967 Donald Edward Fuhrmann 
The Effects of Drive and Feward upon Concept Forsation In Sch1zophrenia

Donald Edward Fuhraenn

A Dissertation Subnitted to the faculty of the Grsduate School of Loyola University in Partial Fulfillaent of the Reguirement for the Degree of Doctor of Philosophy 
Aaknowledguents

The writer 1o deeply indebted to Drs. Patrick Leughlin, Frank Kobler, and Ronald walkor for their oncouragement, confldence, concern, and continulag support. The writer is albo Indebted to the Paychology Department, chaired by Dr. Alan Rosenwald, of the Illinole State Paychlatric Institute, Chicago, Illinola, and to the Inatitute itself for providint tive. fInances, counsel, and oubjects for the execution of this prom

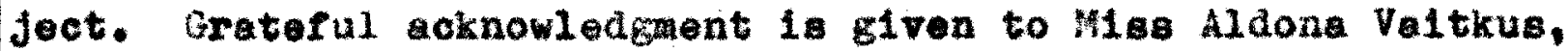
Institute for Juvenile Research, Chicago, Ill1nois, for the use of computer fac111ties. Also, grateful acknowledgment is siven to Miss Mary Evolyn Jones and Miss Jean Maracek for their rellability, attention to detall, and their sugestions as research asistants. Of paremount importance in the 1mplementation of this gtudy wore ay wife, Barbara, and son, David, who sacriflecd mang hours of fanily 21 fo so that an atmosphere of dedication to the research could be created. 


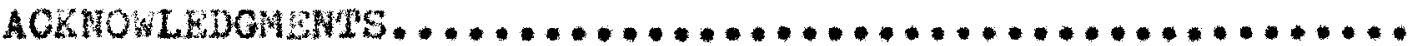

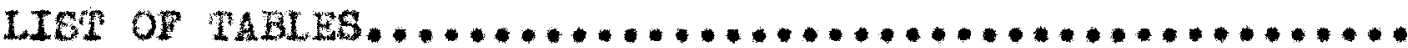

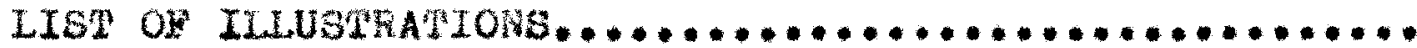

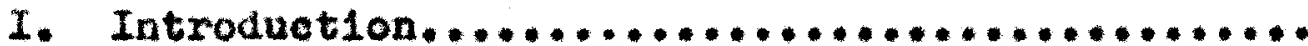

II. Review of Relevant Literature...............

A. Medniok'B theoretical Approach

B. Motivation

C. Dxperinental Manipulation of Motivation

D. Concept Formation Teaks and Motivation

E. Hypotheses

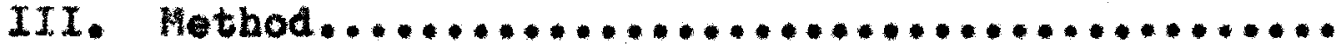

A. Design and subjects

B. Stlmulua Display

C. Concept Vormation Tak

D. Palmar Sweat Index

E. Procedure

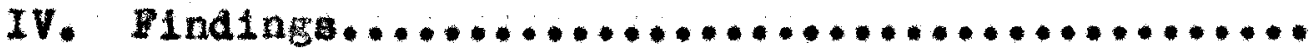

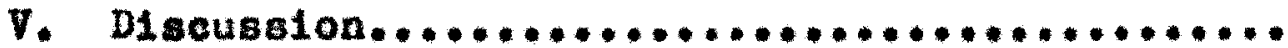

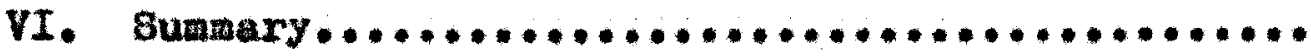

RERERBNCES, $\ldots \ldots \ldots \ldots \ldots \ldots \ldots \ldots \ldots \ldots \ldots \ldots \ldots \ldots \ldots \ldots$ 


\section{MABLE OF CONTENRS (Continued)}

\section{LIST OF TABLES}

Pablo

1. Prequency of Dlagnostic Classifleation for Each

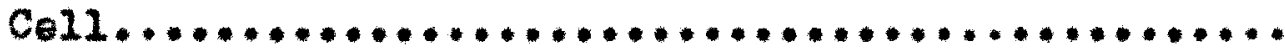

2. Means of Subject Groups for Taylor Manifest

Anxiety Scale, Age, Eaucation, Previous Hoopltal-

12ations, Dags Uoop1tal1zed, sRA Verbal and SRA

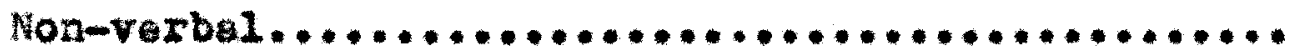

3. Correlations of Verbal and Non-verbel Intelligence

Scores with Dependent Var1ables...............

4. Mrequency of Druge Prescribed for Each Cell........

5. Meane for Focusing Strates with Complexity as

Repeated Measure..........................

6. Mean for Pocusing Stretegy with succeastre Prob-

1ens as Repeated Measure.....................

7. Analyols of Varlance for Focusing Strategy with

Complexity and with Successlve Problems as

Reperated Measuros...........................

8. Heans for Bcannine StrateEy with Complexity eB

Repeated Meagure............................

9. Means for Scanning Strategy with Successive

Problens as Repeated Measure.................. 
TABLE OR CONTEMTS (Continued)

LIST Of TABIES (Continued)

Table

10. Analysis of Variance for Beaning Strategy with Complexity and Successive Probleas as Repated

Mersures......................................

11. Heans for Untenable Hypotheses with Complexity

as Repoated Measure...........................

12. Means for Untenable Hypotheses with Succesalve

Problems as Repeatea Measure......................

13. Analysis of Variance for Untenable Hypotbeses with Coaplexity and Successive Problens as Repeated

Messures....................................

14. Mens for Cholces with Complexity as Repeated

Measure...................................

15. Mean for Chotces with Successive Problems as

Repeated Measure..............................

16. Analysis of Varianee for Cholees with Complexity

and Successive Problems as Repeated Measures.....

17. Means for tire with Complexity as Repeated Measure

18. Heans for pime with Successive Problems as

Repeated Messure...............................

19. Ansiysis of Variance for the witb Complexity and Successive Probleme as Repeated Hessures......... 


\section{PABI.E OH CONTBNTS (Continued)}

\section{IIST OR ABliss (Continued)}

Table

20. Heans for Perceptual Inference Errore with

Complexity as Repeated Heasure................

21. Means for Pereeptual Inference Brors with

Buccessive Problems as Fepeated Measure.........

22. Analysis of Vartance for Perceptual Inference

Errore with Complexity and Successive Frobleme

as Repeated Measures.........................

23. Heans for Palmar Sweat Index with Complexity as

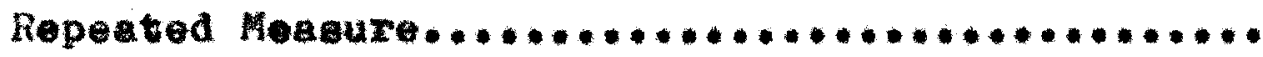

24. Meang for Palmax Sweat Index with Buccessive

Problews a Repeated Measure...................

25. Analysie of Vaxiance for Palmar Sweat Index with

Complexity and Succesalve Problems Repeated

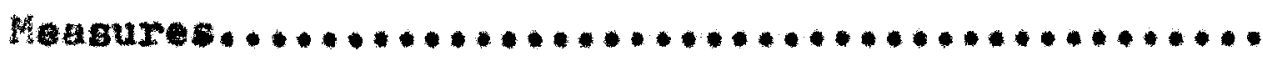

26. Correlations of Dependent Varlables............. 


\section{TABLE OP CONTEMLS (Continued) \\ LIBY OP ILLOSTRATIOKS}

F1gure

1. Dxive $x$ Reward $x$ Complexity Interaction for

Foousing Strategy $\ldots \ldots \ldots \ldots \ldots \ldots \ldots \ldots \ldots \ldots \ldots \ldots \ldots \ldots$

2. Dxire $x$ Reward Interaction for Seanning

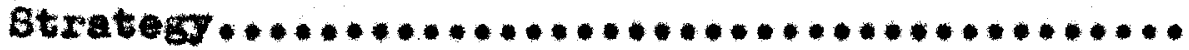

3. Drive $x$ Reward $x$ Complexity Interaetion for

Beanning Stratogy $\ldots \ldots \ldots \ldots \ldots \ldots \ldots \ldots \ldots \ldots \ldots \ldots \ldots \ldots \ldots$

4. Reward $x$ Couplexity Interaotion for Untenable

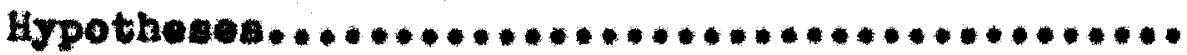

5. Drive $x$ Reward $x$ Conplexity Interaetion for

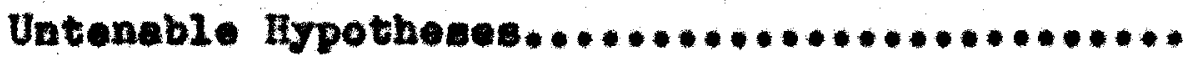

6. Drive $x$ Rowand $x$ Complexity Interaction for

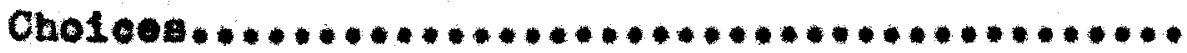

7. Drive $x$ Roward $x$ Complexity Intereotion for

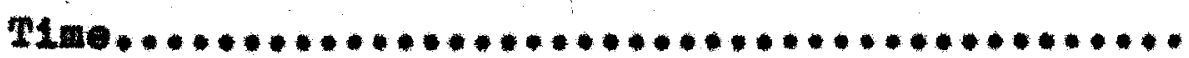

8. Drive $x$ Reward $x$ Complexity Interaetion for

Perceptual Inferenee Erore................ 


\section{Chapter I. Introduction}

The conceptual defielt in echizophrenia has been deseribed as the inability to think abstractiy (Coldstein, 1944, 1947. 1959) and, conversely, as the tendency to over-abstract, to over-generalize, and to over-include (Cameron, 1944), Clinleal experiences with echleophrenies in a sort-term, inpatient poyobiatrio hospltal have revealed to this writer waxing and waning of the schizophrenie's ability to abstract and conceptuallze. Occasionally the schizophrenle seens to posess remarkable conceptual capacitien, yet, nost frequently, such abetraeting abllitios ar elearly not utilized. Investigating the sehizophrenic conceptual deric1t, MeGaughran and Moran (1956) found ehronic paranold achisophrenics to be lallar to non-poychiatric control aubjecte in thelr conceptual abilitiea, but the sohizophrenic's ability to communicate socially was found to be 11mited. This disaertation provided a mothod of -valuating several other paranetere of the conoeptual funotioning of psychlatric In-patients and of sohizophrenics in particular.

The purpose of this otudy was to clarify the nature of the conceptual deflelt in schizophrenle, by investigeting the effects of drive and reway as motivational variables and by 
examining the effeots of the complexity of the conceptual task 1taelf.

Hypotheses

the flrst of three hypotheses (I, II, III) were derived frots three prifary conceptualizations of schizophrente thought procosses: Caneron (1944); Coldste1n (1944); and Modalck (1958) Lypothesos I. II and III are thls researcher's applications of Cameron's, coldstein's and hednick's polats of viow. It must bo eaphakized that these hypothoses are those that each theoreticlan would predict. This experimenter ald not expect Cameron's, Goldstein's, or Mednlck's theories to bo gupported. Instead, Dypotheale IV reflects the expectations of thls experisenter. liypothesis IV, then, 1 asentially contradletory to Hypotheaes I - III and represents the prinary concern of this dissertetion. H1rgt, Cameron"g (1944) over-generalization, overinclusion concept auggegts that schizophrensce should perform more poorly than nonschizophrenies on conceptual tagks (Hypothesls IA). Also, Cameron subcesta that a shizophrenic confronted with a cowplex problem would function fore poorly than one confronted Wth a simple problem (Ilypothesis 1B). Second, Goldstein's (1944) concept that the schisophrente thlnks in a concrete fashion to avold catastrophic anxiety indicates that schizophrentc ahould pexform more poorly than nonschizophrentes on conceptual tasks requirlag abotrections (Hypothenis IIA). If concrete thinking does result from avolding oatastrophic 
anxiety, then it would be expected thet low drive ach1zophrenies would function more poorly on conceptual taske than high drive sch1zophren1es (Hypothesla IIB). That 1s, low arlve schizophrentes have alroagy mintrizod their artve levels by thlnking in a concrete foshion, while high drive schlzophrentes can abstract better, since they have not yet brought their anxiety under control by thinking in senerally concret rashion.

Th11d, Modnick (1958) suggests several hypotheses based upon learning theory. Because high drive should foster greater generalization in responding to irrelevant cues, bigh drive subjects should have more difficulty in concept formation than Low drive subjects (Hypothes1s IIIA), H111 (1960) belleves that Increased drive would strongthen the relovant response in an amount directly proportionsl to the irrelevant responses. This researcher agrees with 11111 (1960) and expects that high arive and low drive subfects should conceptualize in a similar fashion (Hypothesis III AI). Medulck suggests further that on complex tasks, high drive will ellelt more irrelevsnt responses than w11l low arlve. Thus, an interaction between drive and the complexity of conceptual takks should be slgniflcant (Hypothesis IIIB). Also, hIgh drive subjects should function more poorly than low drive subjects on complex tasks (Hypothesis III BI) and bettor than 2ow drive subjects on simple tasks (Hypothes1s III B2). Hedn1ck suggests that a significant 
Interaction ahould be expectod betweon a clasalfication of schizophroat and nonschizophrania and drive levela of high and Low drive (Gypothosis 1IIC). Schizophrenica should function better than nonschizophrenics on slaple tasks (Hypothesis III CI) and sore poorly than nonschizophrentes on simple tasks (IypotheBt III CI) and nore poorly than nonschizophrenics on complex tasks (Hypothesio III C2). The above prodictions, with the exception of lypothesis III Al, are those predictione when would be ande by cameron. Coldatein and Mednick, but not by tbis experimenter. Those three theoreticlans have not aquated their abject amples for arlve levels and therefore aay be somewhat inaccurate in their conceptuallzation of achisophrenla. That 18, the schizophrenic thinking deficit whlch they describe way have nothing to do With schlzophrenla ab such. The deflest ay lnstead be related to diffexences in the dxive levelo of the schlzophrentc group and the nonachicophrenic group. Therefore, if drive level are equated for cenizophrente and nonsobizophrenic broup, it is the expectation of this researcher that no algnificant differences in the concept formation processes w111 obtain betwoen schizophrenice and nonschizophrenics (Hypothosis IV). No specifie hypotheses were ade retarding the effects of nonverbal. non-aversive reinforceaent upon concept formation. alnce this was ossentially an exploretory aspect of the project. 
Also, the relationship of palvar sweat measurements to the ottex variables was en exploxatory appect. 
Chapter II. Review of Relevant Ifterature

A controversy has existed for several decades regarding the nature of the conceptual deficit in schizophrenia. This controversy had originated primarily in Goldstein's thooretical approach that the schizophrenic dificit, which be defined as the Inability to think abstractly, was essentially an attempt to avoid catastrophic anxiety (Goldstein, 1944, 1947, 1959). Another view was taken by Cameron (1944) who emphasized the schizophrenic's tendency to think over-abstractly, to overgeneralize, and to engage in the overinclusion of stimuli. Wuch of the recent research has tended to support Cameron, as well as to lend credence to another of Cameron's hypotheses that situations lnvolving interpersonal relationships are emotionally arousing for achizophrenics and contribute to their conceptual deficlt (Cameron, 1938, 1944; Cameron and Magaret, 1951). Unt1l the middle 1950's there had been little consideration in the ilterature regarding the cognitive functioning of particular types of schizophrenia; that is, schizophrenla had enerally been considered in reasearch as a unitary phenomena with regard to the thinking deficit. The three theoretical approaches to the schizophrenic deficit, the 
labbility to abatract, the tendeney to overinelude, and the anxlety aroused by social sttuations, do not ween to be in ouch autuel oppoestion as the duration of the controveray might augesest. They mey lastead be directiy related, if one considers thelr implications in terne of a learning theory approach to thinking disorders, with partioular emphaeds upon the effects of motivation upon the coentitive processes.

Modnlok's Theoret10al Approseh

Modnick (1958) presente an interprotation of sohlzophrenta based upon llullian and Spenclan prinelples of learning theory, which cuggeste an apparent bridge between paychological theory and psychopethology (Johannsen, 1964). As an introduction to his paper, Modnlck auggest that stiwulus generalization and high levels of anxiety may be "mutually supportive and augmentative." As enxiety increases, the tendency to generalize increases, thus wldening the stimulus gonerallsation gradient. On the other hand, Mednlok ouggest that stimull which are slmilar to the orlginal anxiety producing staulue, or stinulus complex, hould contribute to an inereased level of arive. It 18 the intent of this dissertation however, to utilize only the conception from learning theory that bigh arive contributes to greater stimulus generallation, and not thet generalization creates an inereased level of drive. It is expected that greater drive and hence greater generalization may contribute 
to diffeulties in sequentiol thought and concept formation. These difficultios arlae because the "efrect of helghtened drive 1. to increase the response strength of any hebit tondencies that may be aroused in efven gituation" (Mednick, 1958). The habit tendencies aroused provide a mon larger number of possible responses within alven situation. Perhaps confusion resulte frot the more intense conpetition of responses during belghtened drive. Fill (1960), however, objects to this theoretical framework on the basis that incressed arlve should not only increase the number of response alteratives, but also should eugment the response strength of the correct respoase in an amount alrectly proportionsl to the response strength of the responee alternetives.

In addition to stating that the effect of heightened drive 1s to Increase the responge strength of any hablt tendencies that may be aroused in a given situation, hedntck (1950) aloo sugerest that when the nuwber of responae alternatives is restricted, high drive would augment the response strength of the conditioned reaponae. Reaearch has supportod this hypothesle. For example, studies in classical conditioning vtilizing 11alted rasponse tendenc1es, dononetrate that high drive subjects have greater respones atrength. 1.e." perform better than low drive aubjets (Taylor, 1951; Spence and Taylor, 1951; Spence and Parber, 1953). Research has also demongtrated that when response alternatives are restricted, sehizophrenics do in fact 
condition faster, perform beter, than norals (crylor and Spence, 2953 , spence and taylor, 1953).

In complex learnling tagks, ang lrrelevant and lncorrect babit teadencless are aroused, the number of respones altennatives are augented, and coapeting response altuations oxist. Mednlck (1958) states that high arive, actine 1mpartially upon correct and 1neorrect response tendenc1es, w111 tend to pliah many Irrelevant responses above the evocation threenola. Hita statenent is well supported by research in verbal learalig (Hunt and Cofer, 1944). For oxaple, Tajlor (1950) found that blgh anxlety subjects were superior to low anxiety subjecte when intralist imllarity was low (few sompoting nesponses), but were Inferior when Intralist slmilarity wo high (many cometing responses). Hednick then predicts thet, since schizophrenics (aeute) possess bigh drive, they w111 respond more alowily and with more errors than normals in complex tak altuations. Mednick relates bis hypothoes directig to thinking disorders, In three predictions about performance on peyohologlcal taska which difforentiate sohizophronics from noreala! (1) sohlzophrentes more easily acquire conditioned reaponse (2) show greater etimulus generelization reaponeiveness; (3) have great dfficulty perforaing well in complex eltuations, being plagued by 1rrelevant, tangential aseoclative responses competing with the adequate mode of responee; however, they do at least as well as norwe $2 \mathrm{~s}$ on low complexity taks. 
These predictions hold for both ehronic and acute ackizophrentos, but for different roasone, acoording to Mednlck. The acute senizophenic possesses hich arive and, therafore, the predictions are ade on the drive hypotbesis. The chronic schdzophrente ovidently exhibits low drive, yet hednick sugfeste that the chronlc sohlzophrenle had to experience excessively blgh drive lattally. That is, extrealy high drive allow the chrontc schizophreale to respond to the oxtremes of the goneral1zation gradient. Hednlek postulates that responding to irrelevent, non-anxiety producing stiauli, and not to relevent anxlety producing etinuli, reduces the drive associated with the relevant cues, thereby reinforclag the 1rrelevant responses.

Buss and Danioll (1967) enphasize that Medniok noglecta to specify whother his statements about generalization in scidizophrenics rofer to alated, verbel generalization and/or to primary stimulus generallzation. heanick (1950) attes dimensions auch as pitch (Garmezy, 1952) as providing evidence for his position, yet he scans to apply the theory to both types of genersization. Buss and Daniell's (1967) study utillzes a peroeptual, size estiation, seneralization task and rovealo that the generalization gradient of chronic gehizophrenics and normals are not sifnificantly difforent. However, no statement can be made regarding the more acute schizophrenics, since none were ineluded in the study. The experimentere apparently accept the questionable asaupption that chronic schizophrentce posesss 
low drive lovels and acute schizophrentes possoss high drive levels. It seems highly appropriate then to consider high and Low drive levela in schlzophrentes in teras of Mednlck's theory, rather than on the dinension of acute and chronic schizophrenta. Broen (1966) attempts to intograte inconstetencies in research on sehizophrenla. phe contradietory findirgs clted are:

1.4. Overinelusive concepts have been found in chronto selizophronion (Chapan, 1961).

1.b. Overinclusive thinking is found in many acute sehizophrenics, but chronic sohizophrenics are not overly inelusive (Payno, 1962).

2.4. Obronie schizophrenice attend to a narrower range of stimul1 than nornals (Vonables, 1964).

2.b. Chronic schizophrentes are distractible

than norwals (Chapman, 1956).

Broen ougrestis that these contzadictions aay be elarifled by the following propositions: a. response disorganization characterizes both acute and chronic achizophrenics, and b. chronic sehigophrenice attempt to cope with response disorganisation by observing fower atimull. Ho makes several further hypotheses. First, on tak baving slagle relevant atimulus which evoies neveral response tendeneles, echizophrentes w11 show more disorganized variation than normala. Becond, in multiple stmulus tasks, acute schlephrentes, possessing on 
approximately nomal bresth or observation and disorgenized attention hierarchles, have their attention scattored over a greater range of otimuli than nornals or chronic achizophrenice. Third, in auliple stiaulus taks, 11ke acute schizophrenics, chronics possess bnormal reponse dieorganiation and abnoxwally variable attention bierarchles, but only within the 115ited nuaber of atiaull thay have observed, Broen's hypotheses were not tegted empiricelly. sven though this dissertation 1 not concerned directly with the acute and chronle sehlzophrebic, Broen's ldeas are grounded in a learning theory approach to understanding achlaphrenla, and as such provide feselble conceptusl exanework wheh should Indeed be constdered.

Hechie (1966, p. 282) sumarizes wuch of the existing 11terature by stating that there 12 a "falr weature of agroenont that schizophrenic patientz are patholozioaliy alstractible in that they are unable to ecreen out data 1rxelevant to the task at hand". Much disagreament exists, however, regarding the nature of the distractibility. Over any studies, Wochie (1966) noted that schizophrentos were at a disadvantage when asked to simultaneously aselmilate material in more than one modality. When operating in only one codallty, the sokizophrenic copes much better in the auditory rather then in the visual nodality. However, any type of distraction ereates marked offect on the schisophrenle's audtory task perforaance. 


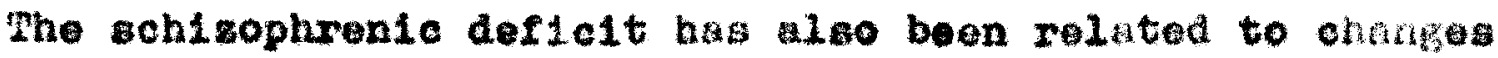
In arousal lovel (Venableo wing, 1962). the consensus accoralng to Lang and Hus (1965) 1 that there $1 \mathrm{~s}$ a dininishod responsiveness in the autonomie nexvous aystem of the chronic schizophrente. Thore is little conclusive evidence; however. Juetifying the psyohophyolologland state of the seute achlzophrende as belng in state of hypo- or hyper-arougal (Venables, 1966). Jasper (1958) susteated that the function of the reticular activeting oystem in normal adaptivo or integxative bohavior way be to provent senoral arousal to all stiauli by selectively respondine to significant stimuli.

Indiseriminate aroual reactione to all otimull coula only result In chaotic behavior as way be the case in come meatal disorders. Thio implles that inhibitory rather than exoltatory functiong any be more 1mportant, elther during aleep or during wakafulness. Venablas (1966) polnte out that the ovidence supportiag the chronic overarousal of the chronte sohteophronio way possibly be brought about by fallure of inhlbitory procerses, while in the acute, there coeks to be a hig degree of varlability in arousal patterns. Venables speculates further that the chronic arougd of the chroule achlzophrenic is the end result of a process by which an over-1ablio and weak lantbitory system eventually becomes inarfective.

The controversy regarding the schizophrenie thinking defielt alst then be clarified in the following manner. 
Pirst, the Goldstein position that concrete thinking io an avoldance of catagtrophle anxiety may be intorproted by polntias out that conerete thinklng cond be the result of high drive and

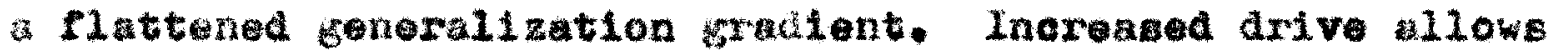

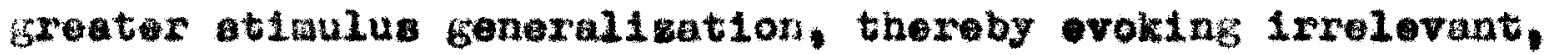
ranote, "concrete" responses lisiting the ochisophronic $B$ ab11ity to consider the rolevant anxiety evoking vtimulua. Secondly, the overinelusion hypotheals eech quite appropriate In that high drtve tlattens the seneralization gradient and allow the aubject to overinelude, that is to reapond to irrelevant stlauli. Mlri, cocial situatione may posege aufficiont dxive producing otimull which cause more genorallsam tion to occur and hence more responses to 1rrelevant stimull. The apparently divergent theories regending chizophrenle

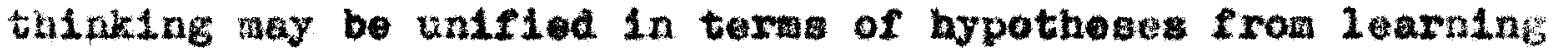
theory. Ano, 1ssueg regarding eroueal algh be Invetigeted by wasuring the palmar eweating, an autononie function, of schisophxale patients.

Notivation

Since we have been discugsing the effecte of drive and cotivation, 1t is essential to define teras. In his alscugsion of motivation and thiaking, Neltzman (1962) delineatos two types of motivatioaal variables: state and process. The state variable refere to "relatively permanent dispostion of tho 
organlaw where the antecedent conditions axe previous inter-

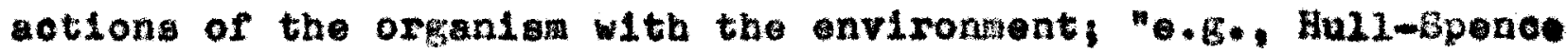
D, arlve Btimuli, hunger, or paylor's drive interpretation of anxiety. Drive w111 be defined in Hullian terms as the ingediate non-specifio atate or general condition of the nervous syster to which all the specifio drives contribute (Hull, 1943). Hull suggeste that arive sene1tises both fac1litative and irrolevant, Interfering habits within siven situation. Fuxtheraore, arive may also bo considered a function of the atrength of an enotional response that la aroused by any forn of averalve stimulation (Spence, 1958). Process varlables Include "hypothetleal, non-observablo, laplicit processes occurring in the individual" (Haltam, 1962) which change rapldiy, are 1abile rathor than persigtent dispositions, and are the nost

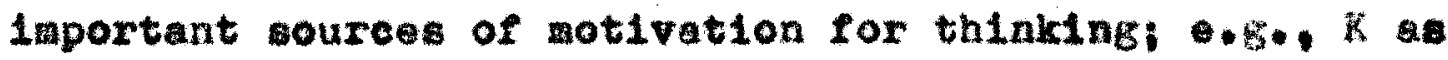
1ncentive motivation, or reward. Incentive motivation, valence, or w11 refer to the expectations of coodness or badness which will result fron a given response. W then refers to the fractional antiolpation of paln or pleanure (Campbell, 1962). Both conceptions of motivation, state and process, w111 be ut111zed in this study.

Two methods of assessing motivation which have beon froquently used in the 11terature are the Maylor Manifest Anxioty Boale, hereafter referred to as (Taylor, 1953) and the Palmar Sweat Index, hereafter referred to as PSI (Haywood, 1963; 
Haywood and Bplelberger, 1966). The Taylor MAB is paper and pencil, self-report queationnalre which consists of MifI thems judged to be associated with the overt expression of or the awareness of anxiety. The MAS has been falrly consletentiy utilized in the extensive research literature as a masure of drive, which is hypothetical construst based upon persistent emotional response in the individual. The PSI is physlological mesure based on the phenomena that environmentel and sensory atimuli may give rise to anticipatory apprehension and may provoke sweating on the palmar alde of the finger tip without affecting a change in general body sweating (Mowrer, 1953; Brutten, 1963).

Experimental Manipulation of Motivation

The intention here is not to review the myriad studies which have manipulated motivation, but ratber to discuss briofly those studies having particular relevance for the experimental variables which are latended to be used in this study. Avorsive Reinforcement. It has been rather consistently found that the utilization of averalve stimuli was falrly successful In 1mporving schizophrente performance. Probably the first and most classical tudy was done by Paseal and Swenson (1952) who found that the diseriminative reaction time of psychotles and schizophrenice was decreased by Introducing blasts of white noise and by requiring rapid responses to terminate this 
avera1ve sound. Cohen (1956), ut111z1ng task involving rote memory and visual motor coordinetion, Improved schizophrenic performance by introducing shock as the averaive stimulus. 31m1lar results, alao uging shock, were obtalned by Rosenbsua, Gribsell and Meckevey (1957). Some experinent usod more complex task than the instrumental coaditioning of wotor responses. Cavenaugh (1958) round that an aversive stimulua, wh1 te nolee, Improved the perforiance of soblzoplarenics even on a concept formation task. Thls task required the bubject to arrange the five cards in each of eleven seto of 1 ive cards in hiererchloal order according to logical, relational concept; e.g., H to the sizes of boxes and 7 according to the period of architecture depicted. Cavanaugh unfortunately reports no alferentiation regarding acuteness or chroniolty of the schlzophrenle sample which he used. Cowden (1962) demonstrated that the perfortance of his seventeen gchlzophrentes on anagram problems 1mproved axkedy whon using white nolse as an averalve stimulus. Cowden also included 17 organtes in his bubject aample who vere aarkodiy debilitatod in their perforianoe by the avoraive stimulus.

Non-averaive Reinforcement. Bince exposure to aversive stimuli 1s Irequentiy considered as unwarranted within an institutional setting, it seens relevant to consider whether non-aversive stimul1 might accomplish similer incroment in sohizophrenic functioning. First, let us consider studies investigating the 
efflcacy of verbal versus non-verbal, non-aversive reinforeemeat. HacDonald and Sheehan (1962) found that Iraproved perfortances on the purdue pegboard and yecbsler aubests were elletted frou echlzophrentos by using conorete non-verbal rewara (rudge). However, on verbal conditioning tasks, verbal lndividual encouragement proved most effective in facliltating perFormence (HacDonald and Bheohan, 1962), S1lberg (1962) also found that sokizophrenies show laproved verbal condtioning during verbal roward, rathor than during reward with elsarottes. In modifying complex behevior using operant conditloning methods, Klag, Armitage and tilton (1960) found that non-verbal forms of response contiagent reward (such as candy, olsarettes, and colored seenlo alldes) were more effective than verbal reward. Robertson (1961) concluded that concrete reward comblaed with verbal praise was most efective in manipulatiags the verbal behavior of chronic achizophrenics, but bis sailure to counterbalance experimental conditiona londs some doubt to the crediblifty of these results. In comenting on these articles, Johannen (1964) states that the majority of atudies find verbal reward elthor ineffective in augenting echizophrente perforance or incapable of eustalning a higher degree or profletioncy.

It Is necessary then to consider the particular effects of non-verbal, non-averelve reinforeenent. K1nis ot al (1957) used cigarettes and candy as reinforcenent for lever proseing in an 
operant conditioning experiment. They suggent that the reinforcements were too trivial for the control and meaningleas for the more alsorlented group, but were gulte effective for the acute schizophrenios. Medalck and Indeloy (1958) fotand no change in the operant lever preasing rete of chronic sehisophrenies regaxdleae of whet type of relnforeer was used. Bullock and Brunt (2959) found soney to be generally an inerfecm

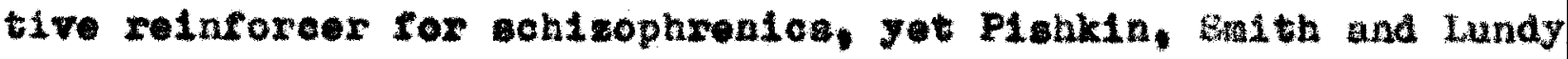
(1962) found money effective in relnfoxelng the verbal condttioning of "early chronie coblzophroulea." Rebearch on wore complex phenoment was undertaken by King. Araltage and pliton (1960). Theix tosk ranged rom almplo operant conditioning to cooperat1ve cocial responding. A barp behavioral laprovanent was obtalned using candy and olgarettes as reluforearant with sehlsophrenied.

Although puntehment or averoive stiall are generaliy accopted as belng the not effective relnforcor for laproving achlzophronlo perrormanoe, some evidence does exlat for

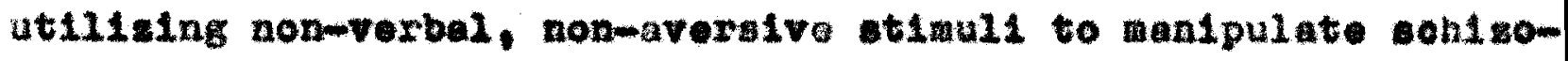
phrenle behavior. The reinforeers of this nature which are nost comanly used are woney, clgarettea, and candy.

Concept Pormation Fask and Motivation

Tho problea of the effocts of hotivation upon coneopt formation task ceme particularly relovant for the current 
doveloping interest in the area of concept formation. Provious studieo regaralag this problew have ut121sed taske which frequently have introduecd confounding factore in the stimulue preaentation. For example, Ha jabredaex'a (1946) task involved presenting the gtivulus cues on anory arum, thereby introduelng the effect of memory and obseuring the ability to form comoepte. The often subtle crect of menoxy in foralng concepts las frequently been confound (Dominowek1, 1965). The

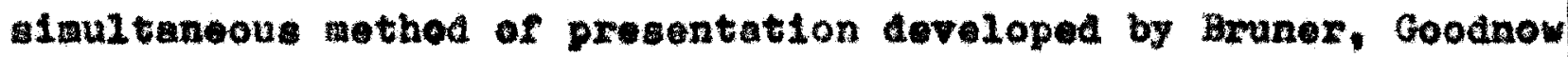
and Austin (1956) which roduce the meacry efrect has rarely been ut1lized in motivational research. The atudies which have attempted to celineate the effects of motivation on coneept formation have employed a vide variety of stimulus cues. s10man (1956) used WaIs subtenta as a wasure of ooncept formam tion, but probleme with his athouolom cause alfiloulty in Interpreting hiv rosulte. Swottand and Chllde-Quay (1958) used Heldbredaer' techntques of presentation, obtaining a memoxy confound, yet they concluded that their "enotionally meladjusted" aubject perforaed better than the "adjusted" aubjects on emotional coneepte. Romanow (1958), in perhaps the most definitive oxperiment to date, utilised word coneepts, by asking the subject to reapond to stiaulus word with concept.

Scorlag was based upon the frequency of the aseociation of the respones word. She found no algnifleant difference between bligh and low anxiety groups when related to eoveept dowinance," 
that is the hlererehy of reapone erequenoy.

Bubirk (1961) used loglosl doductive tasks and flgure analogies from Thurstone's Prlasy hental Ablilties rest. Bach of 60 multiple cholce problens were divided Into four aubtests differing in oomplexty, complext ty deflned as the number of propositions and conelualons for eseb problem. His measuras of manlfeat andety were taken exor interpretations of projective techniques and rrom self-report inventory designed by the experimenter. The subjectio were undergraduate students repistered in psychology courses. Auakirk's fesults do nat sapport his hypothosis that high anxiety performance will show increased intra-takk interference, disorganisation or ego defensivengsa when the couplexity of the conceptual takk is inereased. Some confounding factors seen to exint in Bubirk's atudy: an onder effoct of stisulug preaentation; the use of only undergraduate college studenta; his methods of assessing anxiety level. Glueksbers (1962, 1964), using a problem solving t ak noceseltating the manipulation of materials to comlete an electric clreut, found that High drive lapalred problem solving when response conpetition was high. He folt that the significant interaction of drive lovel and problem diffleulty was in accord with spence's theory or arive.

MeGaughran and Woran's (1956) study clartfies the conceptual functioning of the ohronic poranols ochleophrenic in comparison to non-psychiatric control abjects. Subjecte were 
agtched for age, eduction, and tegt intelligence lovel. supaport's modifleation of the coldstein Object Sorting Iest was used. Fchlzophrenica wore able to funetion in sonctutul fashion without loss of alstrating ab111ty; that it, no sifloant differences obtained bewwen the chronie paruala schizophronles and the controls. However, the achizophrenta demonstrated algnifleant $100 \mathrm{~s}$ of the ablilty to comunicate socially. The conceptul differences betwoen schizophronlca and controls vere related are closely, wh latelleotual lovels than wth the presence or absence of cchtrophrenia. whe schterphrenie deficlt, then, seats to be one of deblittated soolal comandeation rather than any deficit in abstractiag abilaty.

A study investieting concopt formation, wotivation, and achlzophronic thought procassas, utilialng currant findinge in the techniques of accossing the ab111ty to form concepte seema quit relevant, particulariy in 1 ight of the 14 ated reseaxch in the area. 


\section{Chapter III. Method}

Desien and subjects. A $2 \times 2 \times 2 \times 4$ repeated moasures factorlal deaign was used with the rollowing variables: (1) Classirleam tion (Bchizophrenic or non-sehlzophrealc inpationt), (2) Drtre (bigh or low), (3) Reward (yes or no), (4) Complextity (one, two, three, or four 1rrelevant attributes on a concept formation takk).

The eubjects consioted of 40 seblzophrenle and 40 non-achizophrente inpatients living on small, non-locked unite, Both uubject groups were diagnosed ac achizophrente or non-achizophrenic by at least two incependent sources whin

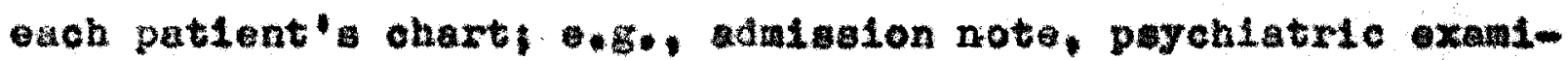
nation, prychological ovaluation, consultant's report, etc. (Bee Table 1). The subjects were assigned to high and low axive exoupe in accordance with the data derived from the Tayl hanffest Anxiety Scale (See Table 2), Each subject was astigned randonly to reward or no reward experimental conditions. The broupe were randomized to that alenifleant differences between eroups would be minlmel on the basls of age, sex, marital status, education, provious hospitalizations and length of hospltalization. Subjects with the dagnonis of organie brain 
syndrome vere not included. Ala, no patent havirg had electroconvulsive therapy within the yoar prior to particlpating in the project wa included in the flasl fubjoct saxple. Fach call contalnad ten subjects.

Half of the cehlaphrente eubjects were rocolviag phenothiazines, while one-fifth of the non-soh1zophronics recelved phenothlaxined (Bee wablo 3). The actual effects of phenothiazines on laaming are inconelualve, stoce there have not been conelusive, parametrie Invetugetiona w1tb controls on relevant vertables. There does, however, sea to bo conocuas that learniag is linited by etrorpromasine, the most comonly used phenothiantne (Bartiago, 1965). Ohorpromaelne blocks the release of neurobomones by the autononic nervous system and rolleve anxiety and tencion, in adation to depreasing the reticular formation and the bypothalanus (Remen et al.,2962). Chlorproaerino has 280 an anti-peycbotle effect, roducing such symptom as halluolnations, delualon end desociation. Therom fore. It must be recognlsed that half of the echlzophrento aubjecte an on modiotions which reduce the echizophronio aymptomatolosy. The adication, however, acte upon cmotional, rather than cognitive, centers of the nerrous syaten. Stinulue Diaplay. The conoept formation task materials conslat of four vilte posterboarda, ouch contalning a diferent number of $2 \% x^{4}$ inoh carde drawn In colorod Ink whth dark out11nos. 
Frequency of Diagnostic Classifications for each Cell

Frequency

Cell 1. Non-schizophrenic, low drive, no reward.

Psychoneurotic depressive reaction

Psychoneurotic anxiety reaction

Pessive-aggressive, passive-dependent personality

Psychotic depressive reaction

Schizoid personality

Cel1 2. Non-schizophrenic, low drive, reward.

Psychoneurotic depressive reaction

Manic-depressive reaction, manic type

Paranoid personality

Passive-aggressive, passive-aggressive personality

Passive-aggressive, passive-dependent personality

Psychoneurotic anxiety reaction

Cell 3. Non-schizophrenic, high drive, no reward.

Psychoneurotic depressive reaction

Psychotic depressive reaction

Emotionally unstable personality

Passive-aggressive, passive-aggressive personality

Cel1 4. Non-3chizophrenic, high drive, reward.

Psychoneurotic depressive reaction

Psychoneurotic anxiety reaction

Involutional psychotic reaction

Paranoid personality

Passive-aggressive, passive-dependent personality

Psychotic depressive reaction

Sociopathic personality

Cell 5. Schizophrenic, low drive, no reward.

Schizophrenic reaction, acute undifferentiated type

Schizophrenic reaction, chronic undifferentiated type

Schizophrenic reaction, paranoid type

Schizophrenic reaction, schizo-affective type 


\section{Table 1 (Continued)}

Cell 6. Schizophrenic, low drive, reward.

Schizophrenic reaction, paranold type

Schizophrenic reaction, acute undifferentiated type

Schizophrenic reaction, chronic undifferentiated type

Cell 7. Schizophrenic, high drive, no reward.

Schizophrenic reaction, acute undifferentiated type

Schizophrenic reaction, parenoid type

Schizophrenic reaction, chronic undifferentiated type

Schizophrenic reaction, schizo-affective type

Cell 8. Schizophrenic, high drive, reward.

Schizophrenic reaction, acute undifferentiated type 4

Schizophrenic reaction, paranoid type

Schizophrenic reaction, chronic undifferentiated type

Schizophrenic reaction, schizo-affective type 
Table 2

Means Of Subject Groups For Taylor Manifest Anxiety Scale. Age. Education, Previous Hospitalizations, Days Hospitalized, SRA Verbal, SRA Non Verbal

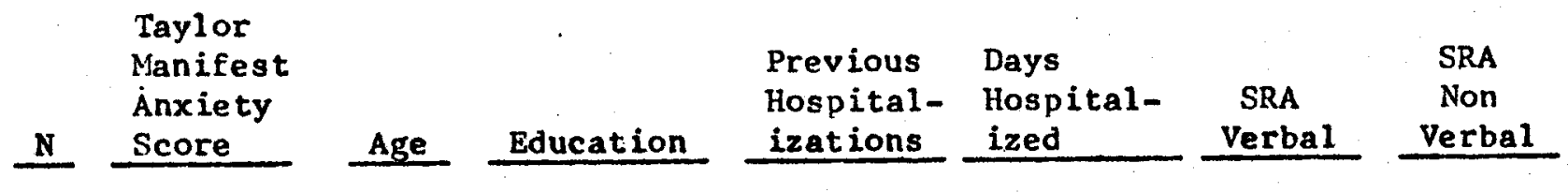

Non Schizophrenic

Low Drive No Reward

Reward

High Drive

No Reward

Reward

Schizophrenic
$10 \quad 18.4$

$10 \quad 18.6$

$10 \quad 36.7$

$10 \quad 35.3$
30.00

28.90

13.40

13.20

26.70

28.30

13.30

13.20

$$
.60
$$

1.10

87.20

54.80

65.90

72.30

33.40

64.50
68.40

75.90

49.40

$1.10 \quad 63.80$

69.50

$\begin{array}{ll}10 & 16.5 \\ 10 & 15.2\end{array}$

25.20

24.20

14.10

13.10

.70

.90
119.40
80.20

1.30

23.80

13.70

$24.10 \quad 13.00$

1.30

105.50
58.00

$10 \quad 32.4$

58.00
63.00

58.70

60.40

50.70

66.90

40.90

37.80

No Rewar
Reward 
The cards were placed on each bosrd in an ordered fashion. These displaye consisted of the followlag attributes and values. Board I: 8 cards differing In (a) shape - square or triangle; (b) Bze - large or Bmal1; (c) color - red or blue. Board II: 16 cards differing in (a) shape; (b) size; (c) colox; (d) number one or two. Board III: 32 carde differing in (a) shape: (b) size; (o) color; (d) number; (e) border - one or two. Board IV: 64 osras differing in (a) shape; (b) alze; (c) color; (d) number; (e) border; (f) design - solid or striped. Any two of those attributes were relevant to biven concept formation problea. That is, the problems varied in complexity from two relevant attribute and one irrelevant attribute (elght 1nstances) problemb to two relevant attribute and four 1rrelevant attribute (64 inetances) probleme. The four boards were presented in random order. The relevent coneepts were predeteralued in a rancion fashion, so as to avold consistent presentation of inherently eas or diffioult problens. Bach subject was given one concept formation problen on each board, so that each subject attempted four problems.

Concept Fornation Task. Any two, of the $81 x$ posalble attributes were relevant in each concept formation problea, The problems then varied in complexity from two relovant attribute and one irrelevant attribute (elght instances) problems to two rolevant attribute and four irrelevant attribute (64 instances) problems. The relevant attributes were prodetemined by 
randomily assigning the possible conbinations of uttributes. Oreat care was taken to establiah a falriy confortable interpersonal rolationshlp between aubject and experimentex. The experimenter met with each subjact at least three times during a two weok perlod prior to the teatiag seasion. Before tosting began, a minimum of 15 minutes was spent chatting with each subject, exploring his alacourort in tho experimental situation, and discussing his expectations about the experiment. The instructions were fiven in an informal, conversational fashion that consistently dealt with the following apecifle topics. The inforad presentation wes necessary in order to continue the rapport already falrly well ostablished with oach subject. Firet, the attributes and levels were explained. beoond, the arrangement of instances on the board were deseribed, in addition to how several instances can be srouped to gother using only two attributes. Whird, tho task was the a explained as finding the combination of two propertiea (attributes) whioh is the regt answer." Fourth, the lothod of finding the correct combination was explained: the examiner indicates one inetance containing the two relevant attributes; the subject then chooses another Inatance; the examinex then indlcates whether or not that ingtance also contalns tho two relevant ottributes; the subject makes a guess bout which two attributes ho thinks aro correct; if his guees is incorrect be chooses another inetance. 
The process continues unt1l the subject finally puesses the correct two atributes.

Palmar Swot Index. The Palmar Swoat Index moanres the autonomic activity ovident via the sweating on the palar surfece of the fingertips. (Brutton, 1963). Tbe aubject's fincex was covered with ferric chlorldeacetore solution and pressed agalnst a $35-m 1111 m e t a x$ f12n 1apregnatad with tanic acla. for thirty seconds at one-half pound pressure. The resulting fingerprinta varied in the density of the ink formed by the combination of the chemiods and weat. A Lab-ine Sudorimetor was used for this procedure. A circular area approxirately threo-sixteenthe of an 1nch in dameter was located around the center whorl of each fingerprint. Using a Lab-Line Deasitoacter, the arount of $11 \mathrm{gbt}$ fron a constant aource passing through that circuler ares fell upon photobenativo ce11. The donsity of the print was then resiaterod in millaxperes. The instrument and its wechanies was explalned to each subject, in order to recuce tho abject's anxiety in being confronted with strange lnatrument.

Procedure. In the rirgt testing assion, subjects were Givon the Taylor Manjest Anxiety sealo in group setting of approxibately thirty patients. Subjects were then selecter on the basis of hish and low diagroses of schlzophronia or nonsehizophrenta. Ihe 1ultial thirty subjects selected were given both the concept formation 
task and the SRA Verbal and Non-Verbal Pesta in order to deternine the inimal level of intelligence neceasary to coaplete the concept foration task. A lower linit regarding $3 \mathrm{RA}$ scores and education was established for the remalnder of the oubjects: 12 years of educetion and scores in the 15th percentlle or higher. In the second teotlng sebston, all rewalning bubjocts were adulnisterad the Palmar Sweat Index, the Coneept Poration Pask, and the sut pate.

The second session conslated of the following. Palmar sweat aeasurements were takent three adaptation prints and one print during the first thirty soconds of the presentation of each concept formation board. The concept foration task was explained after presentation of the flrbt board. The subjecta In the roward condition were told of the reward. whloh was three clgarettes for completing each problen. Twelve cigarettes, the maxinum rowerd, were placed in plain sight between the oubject and the board during concept formation taks. Finally, each subject completed the SRA Verbal and Von-Verbal Foras. Iheso tests are brief, self-administered and indicate a grost levol of intellectual functioning, the experimenter was unaware of the schizophrenio or drive olassifleations of the subjecto during tosting. 
Chupter IV. Hindings

Subject diatribution

Because the subjects were assigned to celle accorilng to diagnostic elassification (non-sehizophrente snd schizophrente) and arive level (high and low), It is laperative that aifferonces between cell samplos be evaluated. Table 2 describes the subject sample along the dimensions of The Paylor Manifest Aaxiety Scsle, age, years of education, days hospitalled, the number of previous hospltalisations, BFa Verbal and Non-verbel Bcores. Ualng Duncan Mult1ple Fange leste (Bdwards, 1962), no significant difference obtalned for age, education or for nuaber of previous hospltalizations. A sigulfoont difference occurred between high and low arive groups on the Taylor hanifest Anxicty Beale at $\mathrm{g} L .001$. There was algnificant dfference ( $2<.05$ ) for days hoepltallzed between the schleophrente-high drive-no reward group and the following cells: non-sehlzophrenie-high arlvo-no reward; non-schizophrento Low drive-reward; and schizophrenlc-blgh dxive-reward. These signiflcant differences are attributed to one patlent who was hospltallzod 463 continuous days prior to testing. 
Megsures of Intellectual functioning were included in the study in order to paxtial out posible alfferencea in intellectual level which could confound the reaulta. Table 2 describer the low correlations between the dependent variables and the verbal and non-verbal intelligence scores. Wo elgnificunt differences obtalned between cella on verbal intell1genee as weasured by the SRA Verbal Forre Howevor, for the BRA Non-verbal form, the higher acores in the non-gehleophrentohigh drive-reward group differed from the lower acores in the non-sch1zophrentc-low dxiveno reward broup at the 05 level (a00 2ablo 3).

Paychotrople medication were proserfbod for 57.5 percent of the subjects (see Table 4). A ohl square teat for $k$ Iadependent amplen (we1gel, 1956) was done in order to di acover whether any signifleant diforences existed between groups resarding the erequenoy of certain preseribed wedications. In addition to no drug otegory, medlcatione were grouped as follows: (1.) phenothieatnes (2.) benzodiazepines; (3.) albenzazeplnes. There were no significant afferences in the use of wedications between hish and low drive groups nor botween reward and no reward groups. The schizophrentc abjocts did recelve signifleantiy phonothiozines than the non-schizophrento aubjects, $x^{2}(3)=9.17,2(.05)$ 


\section{Table 3}

Correlations of Verbal and Non-Verbal

Intelligence Scores With The Dependent Variables

Verbal

.13

$-.07$

$-.15$

$-.07$

$-.13$

$-.19$

.02

\section{Non-Verbal}

$$
.05
$$

$-.07$

$-.16$

$-.07$

$-.14$

$-.18$

$-.06$

Palmar Sweat Index 
Table 4

Frequency of Drugs Prescribed
For Each Cell

Pheno-

thiazines
Benzo-

diazepines
Dibenza-

zepines
No

Drugs

Non Schizophrenic

Low Drive

No Reward

Reward

2

0

1
4

7

4

1

1

High Drive

No Reward

Reward

1

1

2

6

5

Schizophrenic

Low Drive

No Reward

Reward

4.

0

0

0

6

5

1

4

High Drive

No Reward

Reward

1

5
1

2
2

3 
Dependant Variables

the dependont variables on the concept forvation task were:

(1) rocualng strategy (Laughiln, 1966); (2) scanning strategy (Laughlin, 1966); (3) untenablo hypotheses (Taughlin, 1966);

(4) card cholces to eolution! (5) the to solution;

(6) perceptual 1nference errors (Cah111, Hovland, 1960); (7) the palmar swat index (Hay wood \& Splalberiger, 1966).

Each dependent varlable was evaluated using $2 \times 2 \times 2 \times 4$ repeated measuro analyolo of variance. The repeated measures ware for the four concept formation problom presented. Two analyaes of variance vere done for each dependent variable. First, the repeated moasures were consldered in terms of increasing problen complexity, wth probloms rank ordered according to the number of irrelevant attributes. Second, the repeated measuras were considered in terns of the order of the presentation; 10.. for suceaselve problems. The analys is we done for guccegsive probleas in order to deterwine whether an order effect extated wheb may have confounded the coxplexity. In the tables which present the analyees of valance, there 1 a sumary for affects between abjects and two aumarlef for effects within eubjects, one for complexity and one for sucoessve problems. The between subjects data was the same for both coiplexity and suceeselvo problens, since the data 1o obtalnod for between froups by auming acroas problems. 
The Duncan Multiplo Range Feat ws used to deternine which conditions contributed to the sigificant effects.

Roouglax gtretegr. Focualne atrategy lavolves the testing of the relevanes of a particular atribute to the correct hypothe1s. In focusing, the aubjoct selects an instanco which differs from the initial positivo instance in one or more attributes. Scanning strategy, on the other hand, Involves teating specifio Lypotheses unt1l the correct one is found. These strategies were scored according to a sytom developed by Laughiln (1966). Whe oriteria for focusing strategy can be aumarized in three rules. Tule one: each card cholce wust obtain inforation on one new attribute. Ints rule is atiafied if the card choice alters only one attribute not previouely proven 1rrelevant, ox, when nore than one ettribute is altered, the ingtance is poeitive, or the ablguous laformation is correctly resolved on the next card choice by altering only one attribute. Rule two: the hypotheals had to be tenable wth the inforation ovalable. Fule three: the hypothesis could not be repotition of a previousiy given hypothesis. The number of instances of focusing $1 \mathrm{~s}$ diviaed by tha total number of ourd cholees to arrive at a foeubing score within the range of .00 to 1.00 .

No algniflcant eflects occurred between subjecte for focusing atrategy (ate lables 5,6 and 7). A neln effect for the complexity of problotas within subjectio was significant, E $(3,216)-20.71, \mathrm{~g} L .001$ (se0 $\mathrm{mables} 5$ and 7$)$. Fhe concept 
formation tasks 111 be referred to as probloms one through four, according to the number of irrelevant attributes each possesses, for complexity and as the first through fourth problem for succussive problem. Problem one alffered from probl 2 (two 1rrelevant attributes) the tol lovel, from problems 3 and 4 at the .001 level. Problems two and three and problems three and four were not eigniflcuntly different from each otber. Problen two differed from problem four at the .05 level. Ihat 18, as problan became more complex, less focusing occurred. The ilneax trend of this complexity effect is algnificant. E (1, 216) - 33.41, 2 L.001. A signifleant dr1ve $x$ reward $x$ complexity interaction obtained, $\mathrm{E}(3,216), 3.01, \mathrm{R}$ L.05 (see Tables 5 and 7 and Migure 1). Significant differences between subject groups occurred only on problem four, the most complex task, uaing the Duncan fiutiple Range Teot. Low drivomo reward subjects performed nore poorly then low arive-roward subjects at the .05 level and are poorly than blgh driveno roward aubjects at the .01 level. High arive-no reward, high drive-reward, and Low drive-reward subjects ald not differ algnifieantly from each other. For succesalve problems no algnificant affects occurred. 


\section{Table 5}

Means For Focusing Strategy with Complexity As Repeated Measure

Complexity (Irrelevant Attributes)
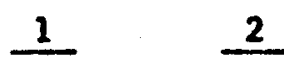

3

4

Total

Non Schizophrenic

Low Drive

No Reward

Reward

.87

.87

.71

.75

.39

2.72

.75

.64

2.90

High Drive

No Reward

Reward

.90

.75

.68

.74

3.07

.97

.85

.61

.48

2.91

Schizophrenic

Low Drive

No Reward

Reward

.82

.69

.69

.74

.36

2.61

.87

.48

.58

2.62

High Drive

No Reward

Reward

$\begin{array}{ll}.95 & .67 \\ .85 & .69\end{array}$

.87

.61

3.10

.55

.46

2.55 
Table 6

Means For Focusing Strategy With

Successive Problems As Repeated Measures

Successive Problems

1

$\underline{2}$

3

4

Total

Non Schizophrenic

Low Drive

No Reward

.79

.56

.65

.72

2.72

Reward

.82

.79

2.89

High Drive

No Reward

.70

.72

.73

3.06

Reward

.86

.71

.69

2.92

Schizophrenic

Low Drive

No Reward

Reward

.78

.65

.47

.72

2.62

.86

.63

.70

2.62

High Drive

No Reward

Reward

.67

.66

.81

.88

.74

3.10

.66

.60

.63

2.55 


\section{Table 7}

Analysis of Variance For Focusing Strategy with Complexity And With Successive Problems As Repeated Measures +

Source

Classification (C)

Drive (D)

Reward (R)

$C \times D$

$C \times R$

$\mathrm{D} \times \mathrm{R}$

$C \times D \times R$

Error (Between Subjects)

Complexity (Co)

Co $\mathrm{X} C$

Co $x$ D

Co $\times$ R

Co $x$ C $\times$ D

Co $\times C \times R$

Co $\times D \times R$

Co $\times C \times D \times R$

Error (within Subjects)

Problems (P)

$P \times C$

$P \times D$

$P \times R$

$P \times C \times D$

$P \times C \times R$

$P \times D \times R$

$P \times C \times D \times R$

Error (Within Subjects)

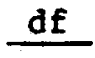

1

1

1

1

1

1

1

72

3

3

3

3

3

3

3

3

216

3

3

3

3

3

3

3

3

216

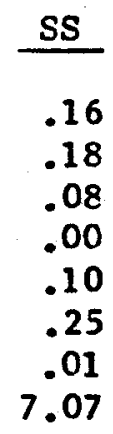

5.16

.06

.04

.66

.15

. .14

.75

.08

17.93

$$
.47
$$

.07

.81

.43

. .29

.06

.33

.41

22.10

\begin{tabular}{lr} 
MS & \multicolumn{1}{r}{ F } \\
.16 & 1.64 \\
.18 & 1.86 \\
.08 & .85 \\
.00 & .01 \\
.10 & .97 \\
.25 & 2.52 \\
.01 & .15 \\
.10 &
\end{tabular}

1.72

.02

.01

.22

.05

.04

.25

.03

.08

.16

.02

.27

.14

.10

.02

.11

.14

.10
$20.71 * \star \star$

.23

.15

2.65

.60

.54

3.01 *

.33

1.53

.23

2.63

1.39

.94

.21

1.06

1.34

t Note that analyses of variance with complexity and successive problems as repeated measures have been combined in this table. 
Figure 1

Drive $x$ Reward $x$ Complexity Interaction

For Focusing Strategy

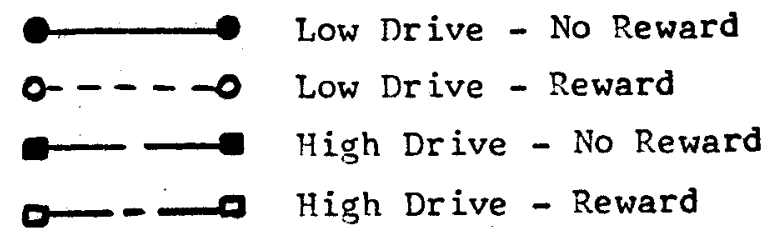

Focusing

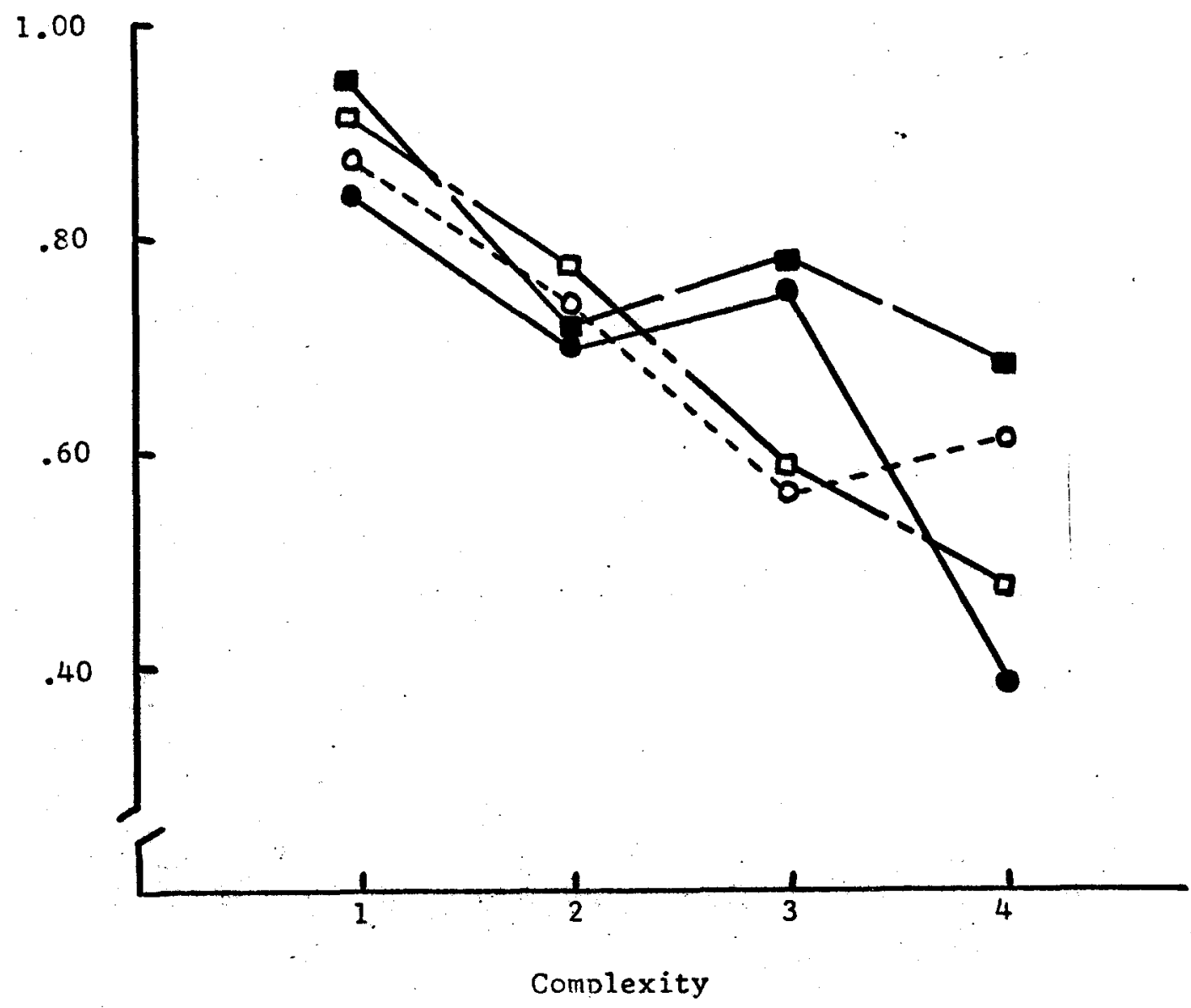

(Number of Irrelevant Attributes) 
Soanning gtrategy. Sounning atrategy involves the tenting of epecifio hypotheses unt1l the correct one 1. found. Ecoring for counning involves tallying all the specific bypotheces disproved by a subject" gueases, then divfline by the number of correct card cholces. The mont efiloient way to acore for bceaning entalls making chart, arrenged by bypotteses, of those concepts elininated by selection of a poaltive instance and those ellatineted by election of a negetive Instance. If a selected card is positive, all coneepta differlng on the given and selected card are ellainatod. If the celected card is negative, all 1dentich corcopte are ellaineted. The number of concepte thus elisineted is addod to the number ollaineted by direot typothasis. The total is then divided by the total nuaber of card oholces. The acaning seore 1s the average number of coneepto liminated on each card cholce.

There was a signifloant arive $x$ raward intaraction for scenning, $E(1,72)-6.41,2<.025$ (soo Tableg 8,9 and 10 and bigure 2). She significonce of the interaction was ecounted for by the dobilitated porforance of the b1gh drive group under the reward conclition $(\mathrm{g}<.05)$ and by the afference in perforaance bettreen the low and bigh drite groupe under the no rewerd condition ( 2 L.01). There was no sinfelcant difference betwoen axive groups under the reverd condition. 
In the analysis of repeated neasurea for complexity, a Ignificant effect for complexity ald occur, $E(3,216)=22.41$, e L.001 (see Tables 8 and 10). Problem one differed from problem two at the .05 level and from problemg three and four at 2 L.001. Problem two aiffered frow problems three and four at E L.001. Problems threo and four were not gignificanty different. Then, as probleme lnereased in complexity, there was tore sanning atrategy used. Frend analysis showed this effect to be 11near, $(1,216)=63.92,2 \angle .001$.

A triple Interaction existed fos arive $x$ reward $x$ complex1ty, I (3. 216) - 5.23, e L.02 (see Tables 8 and 10 and 71gure 3). Significant afferences betwean abject groups occurred only on problem four, the nogt complex task. The low drive-no reward subjecto were found to perforvara poorly than low drive-reward aubjeets $(\mathrm{g} \angle .05)$ and than high drive-no reward

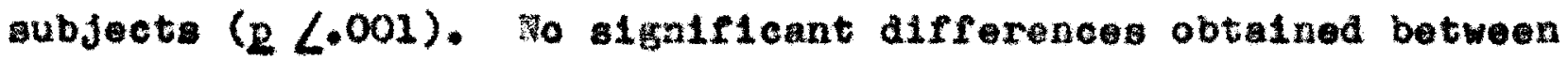
Low drive-no reward and high drive-reward aubjects nor between low drive-reward and high drive-rewaxd abjects. However, the Low drive-reward group performed elgnifieantly nore poorly than the low artive-no reward group $(2<.05)$. 
Table 8

Means For Scanning Strategy With Complexity As Repeated Measure

Complexity (Irrelevant Attributes)

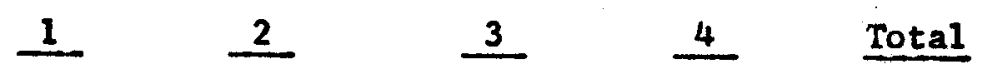

Non Schizophrenic

Low Drive

No Reward

Reward

1.85

2.75

4.01

3.00

3.48

4.40

11.61

1.78

2.50

12.16

High Drive

No Reward

Reward

2.05

1.95

2.75

3.21

3.05

3.52

5.44

3.11

13.45

11.63

Schizophrenic

Low Drive

No Reward

Reward

1.68

2.37

3.23

2.42

9.70

2.25

2.24

3.28

3.46

11.23

High Drive

No Reward

Reward

2.30

2.40

3.75

4.31

12.76

2.00

2.15

3.00

10.02 
Table 9

Means For Scanning Strategy With

Successive Problems As Repeated Measure

Successive Problems

$1 \quad 2 \quad 3 \quad 4 \quad$ Total

Non Schizophrenic

Low Drive

No Reward

Reward

3.00

2.90

2.96

2.75

11.61

3.29

3.08

3.42

2.38

12.17

High Drive

No Reward

Reward

$\begin{array}{ll}3.85 & 3.65 \\ 3.31 & 2.34\end{array}$

3.52

2.43

13.45

2.57

3.41

11.63

Schizophrenic

Low Drive

No Reward

Reward

2.39

2.90

1.89

2.53

9.71

3.56

3.03

2.90

11.22

High Drive

No Reward

2.82

2.80

3.68

3.46

2.50

2.45

12.76

10.03

2.48

2.50 
Table 10

Analysis of Variance For Scanning Strategy With Complexity And With Successive Problems As Repeated Measures

\begin{tabular}{|c|c|c|c|c|}
\hline Source & df & ss & MS & $\mathbf{F}$ \\
\hline Classification (C) & 1 & 8.19 & 8.19 & 3.83 \\
\hline Drive (D) & 1 & 3.14 & 3.14 & 1.47 \\
\hline Reward (R) & 1 & 1.94 & 1.94 & .91 \\
\hline$C \times D$ & 1 & .09 & .09 & .04 \\
\hline$C \times R$ & 1 & .00 & .00 & .00 \\
\hline $\mathrm{D} \times \mathrm{R}$ & 1 & 13.70 & 13.70 & $6.41 *$ \\
\hline$C \times D \times R$ & 1 & 1.11 & 1.11 & .52 \\
\hline Error (Between Subjects) & 72 & 153.91 & 2.14 & \\
\hline Complexity (Co) & 3 & 144.19 & 48.06 & $22.41 * \star \star$ \\
\hline Co $x \mathrm{C}$ & 3 & 7.64 & 2.55 & 1.19 \\
\hline Co $\times D$ & 3 & 6.74 & 2.25 & 1.05 \\
\hline Co $\times R$ & 3 & 1.42 & .47 & .22 \\
\hline$C o \times C \times D$ & 3 & 1.41 & .47 & .22 \\
\hline Co $\times C \times R$ & 3 & 1.50 & .50 & .23 \\
\hline Co $\times \mathrm{D} \times \mathrm{R}$ & 3 & 33.65 & 11.22 & $5.23 * \star$ \\
\hline Co $\times C \times D \times R$ & 3 & 6.66 & 2.22 & 1.04 \\
\hline Error (Within Subjects) & 216 & 463.23 & 2.14 & \\
\hline Problems (P) & 3 & 6.55 & 2.18 & .77 \\
\hline$P \times C$ & 3 & 4.99 & 1.66 & .59 \\
\hline$P \times D$ & 3 & .51 & .17 & .06 \\
\hline$P \times R$ & 3 & 7.62 & 2.54 & .90 \\
\hline$P \times C \times D$ & 3 & 5.95 & 1.98 & .70 \\
\hline$P \times C \times R$ & 3 & 4.18 & 1.39 & .49 \\
\hline$P \times D \times R$ & 3 & 10.42 & 3.47 & 1.23 \\
\hline$P \times C \times D \times R$ & 3 & 16.57 & 5.52 & 1.96 \\
\hline Error (Within Subjects) & 216 & $609: 63$ & 2.82 & \\
\hline
\end{tabular}


Figure 2

Drive $x$ Reward Interaction

For Scanning Strategy

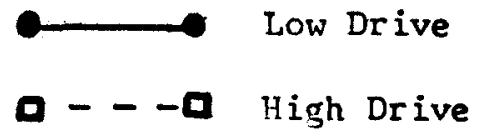

Scanning

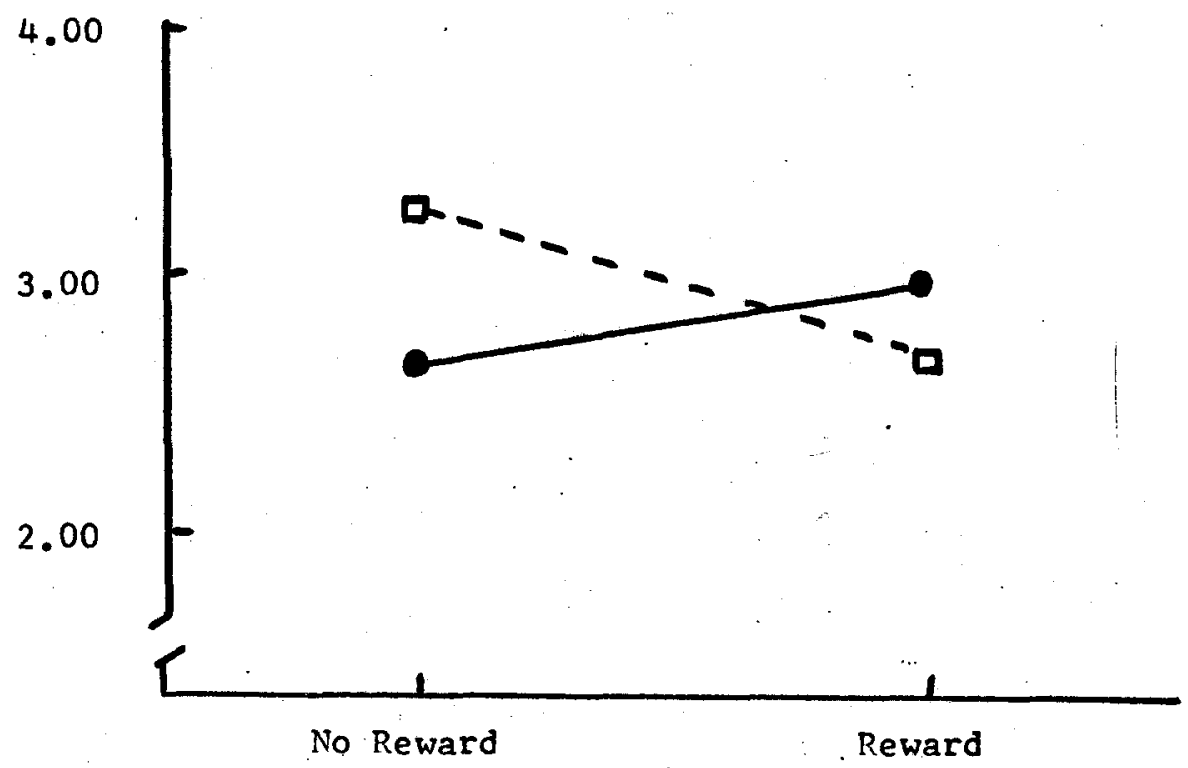


Drive $x$ Reward $x$ Complexity Interaction

For Scanning Strategy
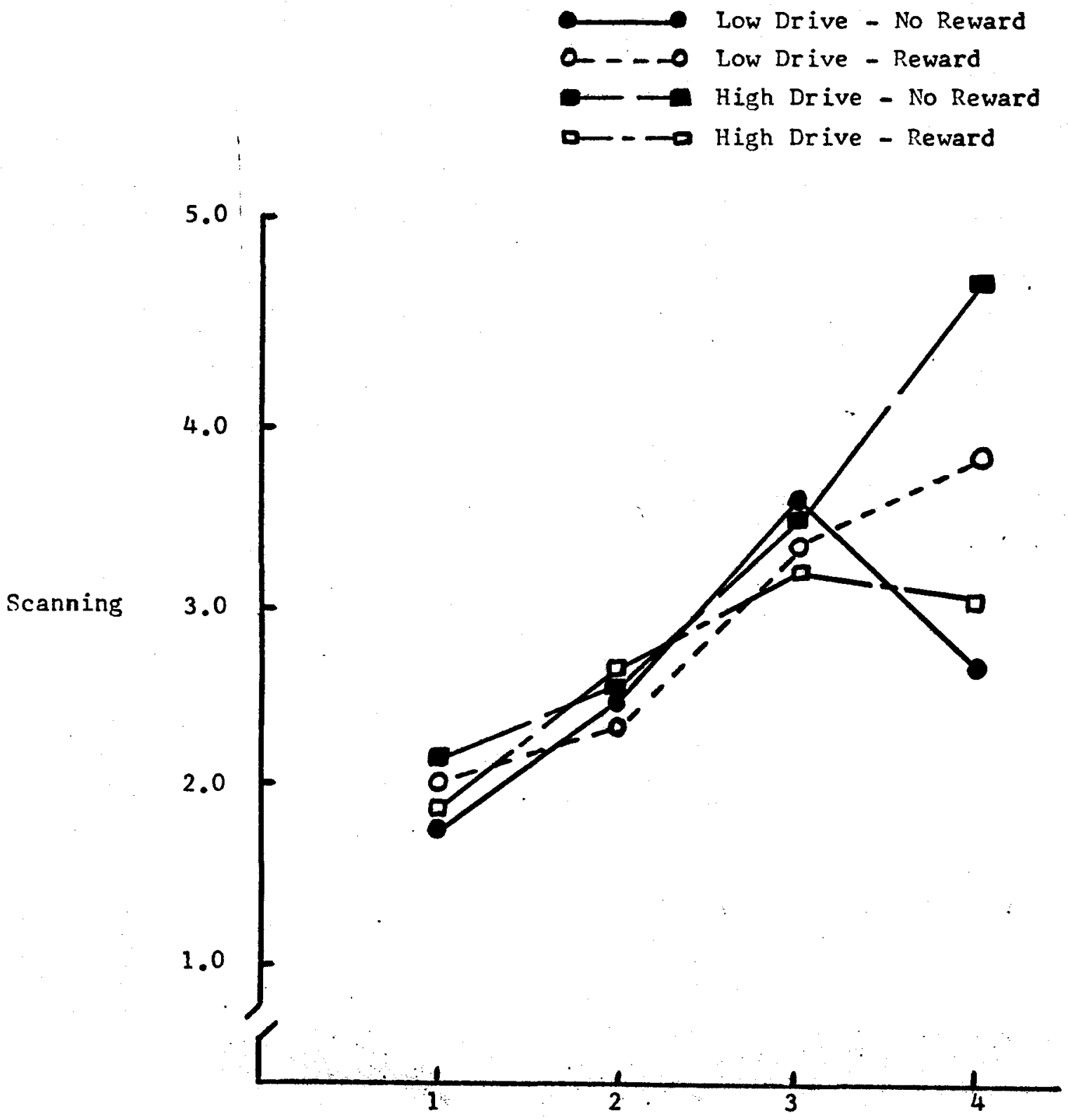

Complexity

(Number of Irrelevant Attributes) 
Intenable trootheses. The nunber of untenable bypotheses which each subject gubritted was obtained by checklng each bypothosis againat those already given for (a.) Inconsistencies with the information already Given and (b.) for repetition of previous hypotheses. (Laughlin, 1966).

No significant effects occurred botween subjecto for intenahlo hypotheses (see Mables 11, 12 and 13). The andysie of the within subject varlance revealed a signiflcant effect for the couplexity of the concept formation taskB, $\underline{I}(3,216)=24.20$, 2 L.001 (see Tables 11 and 13 ). Problen one differed from problen two at $\mathrm{g} L .05$, from problet three at $\mathrm{g} L .01$, and rrom problen four at 2 L.001. Problem two aid not differ significantly from problet three, but differed at the .001 level fros problen four. Problea three also difered from problem four at 2 L.001. As conplexity increased bore untenable hypotheses wore subaltted. The ilnear trend of the erfect was signifieant at $\mathrm{R} L .001, E(1,216)=63.54$. A algnificant double interaction occurred for reward and complexity when analyzing the repeated measures for coraplexity, I(3, 216)- 2.92, e L.05 (see Tablos 11,12 and 13 and 1 isure 4). No significant difforexces obtained for the first three levele of complexity, but on the wost complex task, reward groups perforaod blgnifleantly better than no-reward groups ( 2.05$)$. 


\section{Table 11}

Means For Untenable Hypotheses With Complexity As Repeated Measure

Complexity (Irrelevant Attributes)

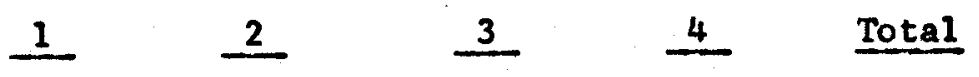

Non Schizophrenic

Low Drive

No Reward

.30

1.00

1.20

5.60

8.10

Reward

.40

1.00

1.60

4.40

High Drive

No Reward

.20

.70

1.40

.30

2.00

1.80

4.70

Reward

.10

1.80

2.90

5.10

Schizophrenic

Low Drive

No Reward

Reward

$.40 \quad 1.30$

.70

5.60 .

8.00

.30

2.60

2.50

7.30

High Drive

No Reward

Reward

.10

1.00

1.40

.60

2.00

3.70

.10

3.20

6.80 


\section{Table 12}

Means For Untenable Hypotheses With

Successive Problems As Repeated Measure

Successive Problems

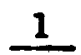

2

3

4

Total

Non Schizophrenic

Low Drive

No Reward

Reward

$.90 \quad 1.70$

$.90 \quad 1.50$

1.90

3.60

8.10

.50

1.50

4.40

High Drive

No Reward

Reward

1.40

.30

1.00

2.00

4.70

.60

1.50

1.20

5.10

Schizophrenic

Low Drive

No Reward

Reward

1.40

1.20

3.90

1.50

8.00

.50

3.70

1.00

2.10

7.30

High Drive

No Reward

Reward

1.20

.80

1.60 .

.30

1.40

2.10

3.70

6.80 
Table 13

Analysis of Variance For Untenable Hypotheses With Complexity And With Successive Problems As Repeated Measures

Source

Classification (C)

Drive (D)

Reward (R)

$C \times D$

C $\times R$

$D \times R$

$C \times D \times R$

Error (Between Subjects)

Complexity (Co)

Co $x$ C

Co $\times$ D

$\operatorname{Co} \times \mathrm{R}$

Co $\times C \times D$

Co $\times C \times R$

Co $\times D \times R$

Co $\times C \times D \times R$

Error (Within Subjects)

Problems (P)

$P \times C$

$P \times D$

$P \times R$

$P \times C \times D$

$P \times C \times R$

$P \times D \times R$

$P \times C \times D \times R$

Error (within Subjects)

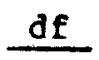

1

1

1

1

1

1

1

72

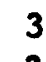

3

3

3

3

3

3

3

216

3

3

3

3

3

3

3

3

216

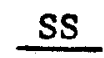

3.83

17.58

.25

1.38

10.15

19.50

.03

403.02

359.96

7.28

24.38

43.46

2.93

8.01

92.21

.93

1071.08

39.41

12.08

9.18

39.06

11.78

17.36

42.66

30.03

1408.68
MS

3.83

17.58

.25

1.38

10.15

19.50

.03

5.60

119.99

2.43

8.13

14.49

.99

2.67

30.74

.31

4.96

13.14

4.03

3.06

13.02

3.93

5.79

14.22

10.01

6.52
$\underline{\mathbf{F}}$

.68

3.14

.04

.25

1.81

3.48

.00

$24.20 * * *$

.49

1.64

$2.92^{\star}$

.20

.54

$6.20^{\star \star \star}$

.06

2.01

.62

.47

2.00

.60

.89

2.18

1.54 
Figure 4

Reward $x$ Complexity Interaction

For Untenable lypothesis

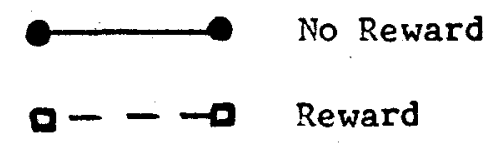

Untenable Hypothes is
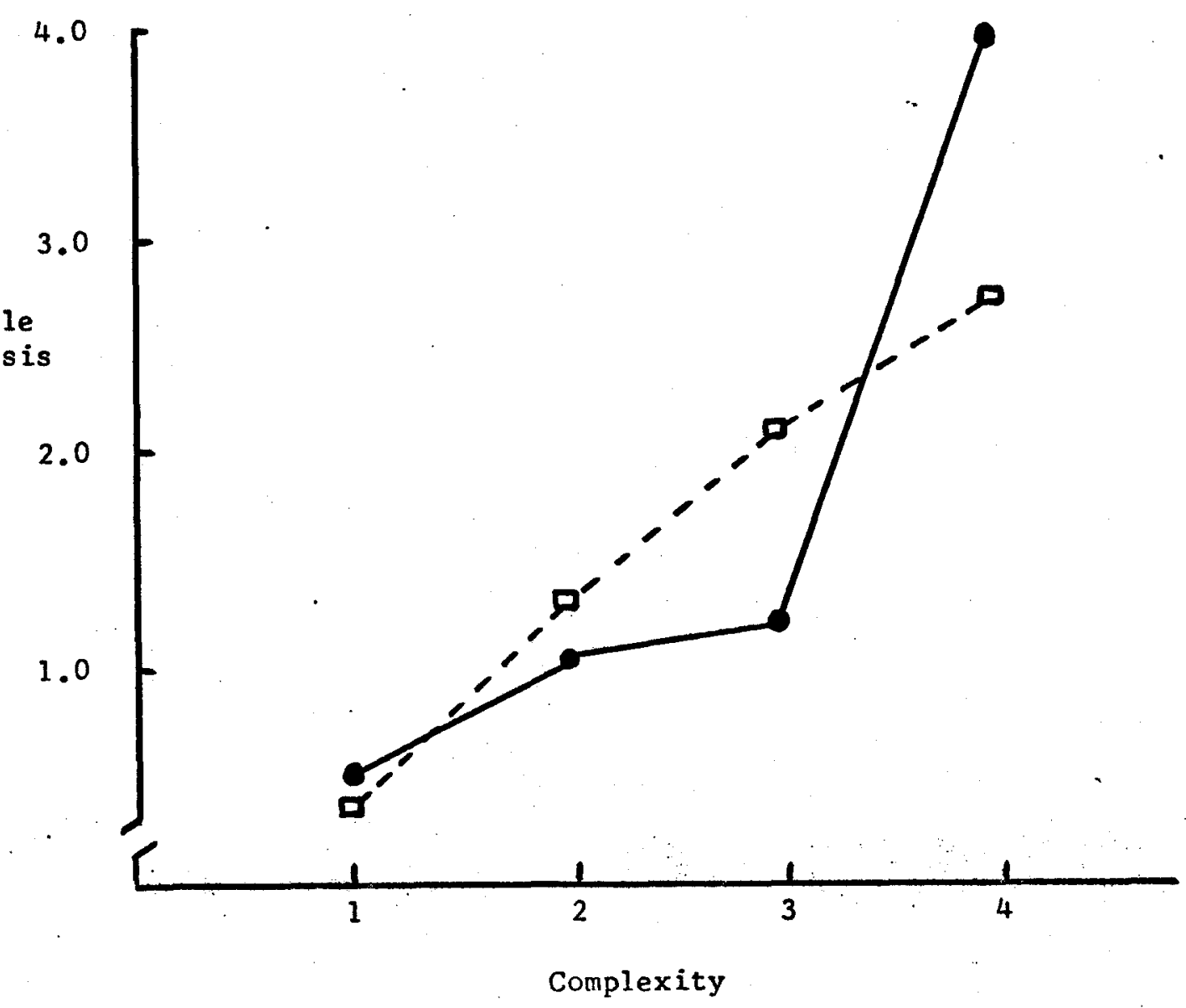

Complexity

(Number of Irrelevant Attributes) 


\section{Figure 5}

Drive $x$ Reward $x$ Complexity Interaction For Untenable llypothes is

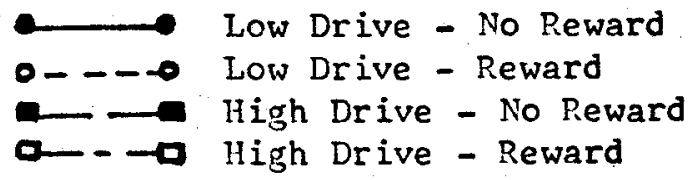

Untenable Hypothes is

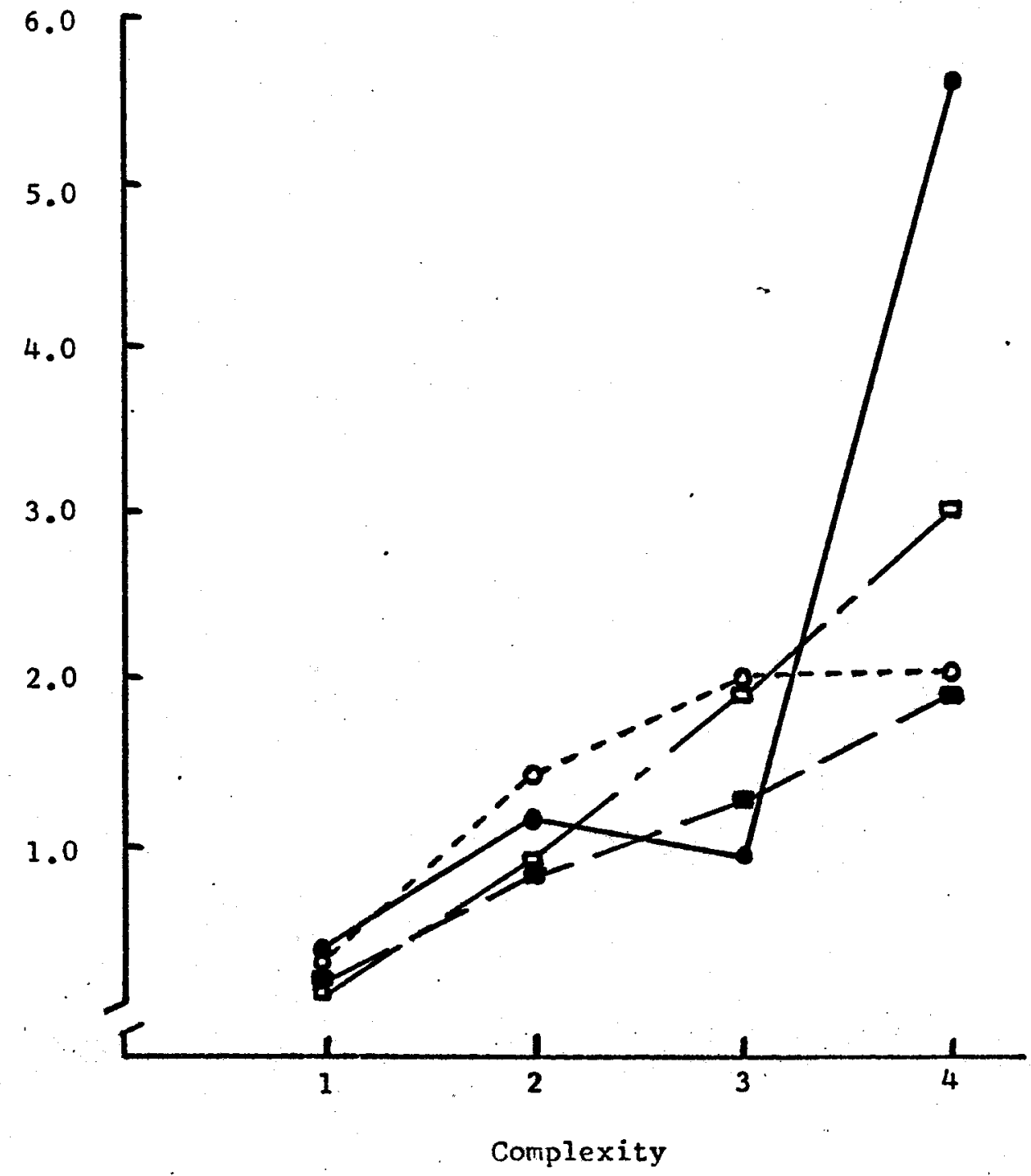

(Number of Irrelevant Attributes) 
A algniflcant triple Interaction also occurred for the complexity of taks between arive, roward and complexity, E $(3,216)-6.20, \mathrm{~g}$ L.001 (sec Tables 11 and 13 and P1gure 5 ). There were no significant differences between groups on the less complex problems one, two and three. On problem four, the low arive-no reward subjecte performed ignifiently more poorly than low drive-roward subjects and high drive-no reward subjecte ( 2 L.001) and also more poorly than bigh arive-reward aubjects ( $(.01)$. The low arive-roward, high drive-no reward, and the bigh drive-reward oubjects did not differ oignificantly from each other. Ther were no olgnifleant effects for successive probloms.

Gholoeg. Scores for cholces to golution were obtalned by totalling the number of card choleas. No signifient difterenees occurred betweon subjeots (see Tables 14,15 and 16 ). A signifleant effect for complexity ald obtaln, $I(3,216)$. 34.30, e L.001 (eee rables 14 and 16). Problen one differed from problow two at $\mathrm{g} \angle .01$, frow problea three and four at 2 L.001. Problem two difrexed from problem three at $\mathrm{e} \angle .05$ and from problem four a $\mathrm{L} .001$. Problem three diftered from problen four at 2 L.001. As complexity increased, more card cholces were ada. The linear trend was slgniflcant $E(1,216)$ $=100.49, \mathrm{~g}<.001$. 
A aificicant triple interaction occurred for dxive $x$ reward $x$ complexity, $E(3,216)=5.57, \mathrm{~g}$ L.005 (Beo rablos 14 and 16 and ficure 6). No signiflcant differences obtalned between groupe for probleas one, two and three. On the most complex problem, low drive-no reward aubjecta performed signiflcantly more poorly than low drive-reward subjects (2 L.001), more poorly than high arive-roward subjects ( 2.01 ) and wore poorly than high drive-no roward subjects (e $\angle .001)$. There were no signifleant differences between blgh drive-reward subjects and low drive-reward subjeots, nor ony algniflont differences between low drive-reward and high artve-no reward aubjects. High arivomroward eubjects ald perfora more poorly than high drive-no revard subjects ( 2.05$)$.

An effect for succesalve problens was singricant at $\mathrm{g}$ L.05. $\mathrm{Y}(3.216) \cdot 2.68$ (ate Tables 15 and 16). The first problem preaented affered gignifleantly from the lant problem at the .05 level, fewex choloes belng nade on the firgt than on the last problen. None of the other successive problems differed significantly frow oech othex. The linear trend was signifleant the .01 level, $E(1,216)=6.90$. 


\section{Table 14}

\section{Means For Choices With Complexity \\ As Repeated Measure}

Complexity (Irrelevant Attributes)

$1 \quad 2 \quad 3 \quad 4 \quad$ Total

Non Schizophrenic

Low Drive

No Reward

Reward

1.50

2.80

2.80

7.30

14.40

1.90

2.70

3.50

3.80

11.90

High Drive

No Reward

1.50

2.20

4.30

3.80

3.40

11.40

Reward

1.70

1.90

5.50

12.90

Schizophrenic

Low Drive

No Reward

Reward

1.90

3.00

3.10

7.80

15.80

1.50

3.60

4.50

5.00

14.60

High Drive

No Reward

Reward

1.20

2.70

2.70

4.30

5.50

10.90

3.30

3.80

13.80 
Table 15

Means For Choices With

Successive Problems As Repeated Measure

Successive Problems

$1 \quad 2 \quad 3 \quad 4 \quad$ Total

Non Schizophrenic

Low Drive

No Reward

Reward

High Drive

No Reward

Reward
3.20

2.30

2.20

2.70

3.40

3.50

3.70

2.30

1.90

3.90

2.40

3.30

3.90

5.10

14.40

3.40

11.90

Schizophrenic

Low Drive

No Reward

Reward

3.30

1.70

2.80

5.80

6.20

3.50

3.90

15.80

3.20

14.60

High Drive

No Reward

Reward

3.10

2.00
2.50

3.30
2.10

4.70
3.20

3.80
11.40

12.90 
Table 16

Analys is of Variance For Choices With Complexity And With Successive Problems As Repeated Measures

\section{Source}

Classification (C)

Drive (D)

Reward (R)

$C \times D$

$C \times R$

$D \times R$

$C \times D \times R$

Error (Between Subjects)

Complexity (Co)

Co $x \mathrm{C}$

Co $x, D$

Co $\times R$

Co $x C \times D$

Co $\times C \times R$

Co $\times D \times R$

Co $\times D \times C \times R$

Error (Within Subjects)

Problems (P)

$P \times C$

$P \times D$

$P \times R$

$P \times C \times D$

$P \times C \times R$

$P \times D \times R$

$P \times C \times D \times R$

Error (Within Subjects)

$\mathrm{df}$
1
1
1
1
1
1
1
72

\section{3}

3

3

3

3

3

3

3

216

\section{3}

3

3

3

3

3

3

3

216

\begin{tabular}{r} 
SS \\
\hline 6.33 \\
18.53 \\
.15 \\
4.28 \\
2.28 \\
20.50 \\
.00 \\
400.28 \\
\\
600.61 \\
14.28 \\
22.68 \\
21.06 \\
8.63 \\
8.83 \\
97.61 \\
4.71 \\
160.83
\end{tabular}

1260.83

64.98

25.16

14.81

58.18

7.06

20.76

61.08

40.38

1746.82

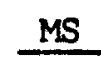

6.33

18.53

.15

4.28

2.28

20.50

.00

5.56

200.20

4.76

7.56

7.02

2.88

2.94

32.54

1.57

5.84

21.66

8.39

4.94

19.39

2.35

6.92

20.36

13.46

8.09

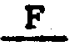

1.14

3.33

.03

.77

.41

3.69

.00

$34.30 \star \star \star$

.82

1.30

1.20

.49

.50

5.57 *

.29

2.68 *

1.04

.61

2.40

.29

.86

2.52

1.66

* $\mathrm{p}<, 05$

$\star \star \mathrm{p} r .005$

$\star \star \star$ p $<.001$ 
Figure 6

Drive $x$ Reward $x$ Complexity Interaction

For Choices

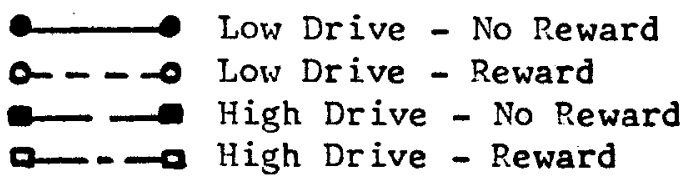

Choices

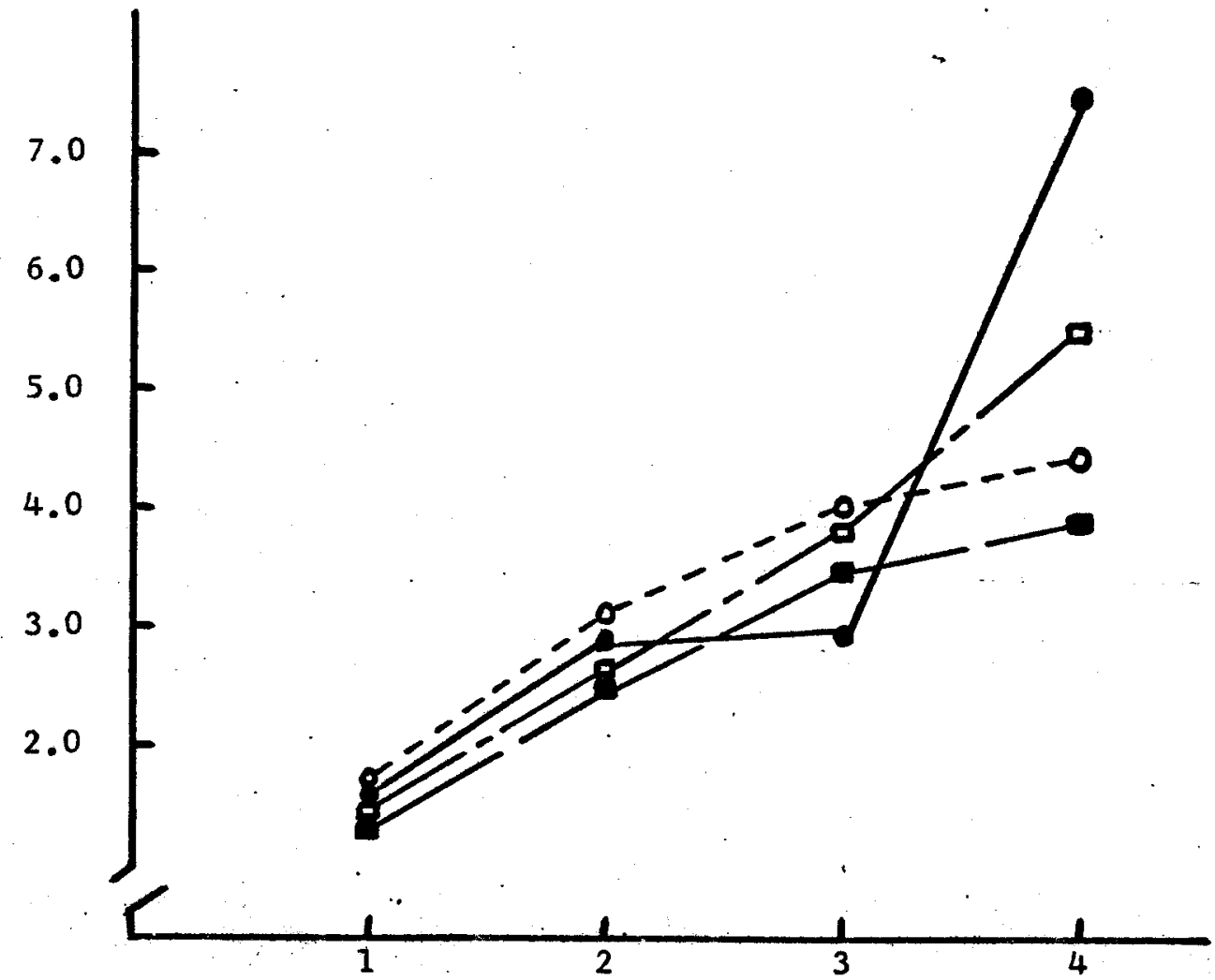

Complexity

(Number of Irrelevant Attributes) 
14mo. Tita in seconds to solution wa another dependest variable. No sienifieant differences were evident between aubjects (ae sables 17, 18 and 19). A slentfioant exfoct for complexity ald obta1n. $1(3,216)=22.93$. L L.001 (see Pables 17 and 19). Froblem one alfered from problem two at $\mathrm{g}$ L.01 and from problew three and four at $\mathrm{e}$ C.001. Problen two ald not diffor signiflcantis from probles three and differed from problen four at $\mathrm{e}$ L.001. Froblen three affered from problem four at $\mathrm{g}$ C.001. As complexity inereased, tine also inereased. The linear trend was stenleleant at the .001 level, $E(1,216)=$ 37.54. A slgnifleant triple interaction robulted lor drive $x$ reward $x$ conylexity, $2(3,216)-2.71,24.05$ (soe 9able 17 and 19 and igure 7). Wo blgniflcant alfferences occurred for problems one, two and three. On the nost complex problen the 1ow drivo-no reward abjects desonstrated poorex perfowance (a 4.002 ) than the other three froups anone which there were no signifleant afferences. No elgniflcant effects obtalned winin subjects for suceselve probloms.

\section{Pereoptual inference errors. Fereoptual inforence erroxs}

(Cab111 Hovland, 1960) were defined in this disertation as those wich were inconsietent with information given on the lamediately precedias two eard seleotlons or those which repeated elther one of the two larediately prooeding hypotbeser. No between subjocts efrecta obtalned algniflcanco (aee Tables 20,21 and 2 ?. 


\section{Table 17}

Means For Time With Complexity

As Repeated Measure

Complexity (Irrelevant Attributes)

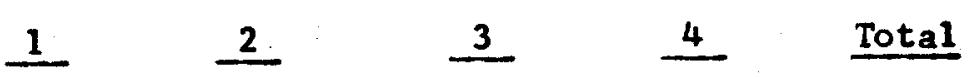

Non Schizophrenic

Low Drive

No Reward

Reward

$\begin{array}{rr}86.70 & 291.50 \\ 168.30 & 193.90\end{array}$

282.50

787.10

1447.80

$297.40 \quad 349.70 \quad 1009.30$

High Drive

No Reward

Reward

$\begin{array}{rr}82.50 & 232.90 \\ 132.30 & 155.10\end{array}$

461.90

497.80

1275.10

372.50

496.10

1156.00

Schizophrenic

Low Drive

No Reward

Reward

$\begin{array}{rrrrrr}107.70 & 267.40 & 291.80 & 692.60 & 1359.50 \\ 108.70 & 269.70 & 365.80 & 450.50 & 1194.40 \\ & & & & \\ 133.60 & 209.90 & 184.30 & 266.80 & 794.60 \\ 59.80 & 341.90 & 373.90 & 488.90 & 1264.50\end{array}$

High Drive

No Reward

Reward

$59.80 \quad 341.90$

373.90

$488.90 \quad 1264.50$ 


\section{Table 18}

Means For Time With

Successive Problems As Repeated Measure

Successive Problems

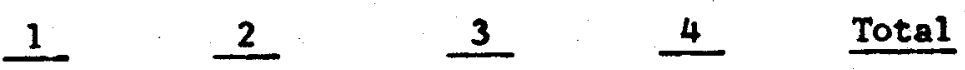

Non Schizophrenic

Low Drive

No Reward

213.10

453.40

409.30

372.00

1447.80

Reward

316.50

302.20

158.30

232.30

1009.30

High Drive

No Reward

Reward

$308.70 \quad 192.10$

267.40

506.90

1275.10

294.80

223.60

221.70

1156.00

Schizophrenic

Low Drive

No Reward

Reward

403.40

208.70

565.40

182.00

1359.50

122.00

533.60

272.80

266.00

1194.40

High Drive

No Reward

Reward

230.40

141.60

231.90

190.70

794.60

183.40

372.40

443.90

264.80

1264.50 
Table 19

Analys is of Variance For Time With Complexity And Successive Problems As Repeated Measures

\section{Source}

Classification (C)

Drive (D)

Reward (R)

$\mathrm{C} \times \mathrm{D}$

$C \times R$

$D \times R$

$C \times D \times R$

Error (Between Subjects)

Complexity (Co)

Co $x$ C

Co $\times D$

Co $\times R$

Co $x C \times D$

Co $x$ C $\times$ R

Co $x$ D $\times R$

Co $\times C \times D \times R$

Error (Vithin Subjects)

Problems (P)

$\mathrm{P} \times \mathrm{C}$

$P \times D$

$P \times R$

$P \times C \times D$

$P \times C \times R$

$P \times D \times R$

$P \times C \times D \times R$

Error (Within Subjects)

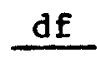

\section{1 \\ 1 \\ 1 \\ 1 \\ 1 \\ 1 \\ 72}

$$
3
$$

3

3

3

3

3

3

3

216

3

3

3

3

3

3

3

3

216

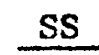

23667.00

84760.00

19971.00

68678.00

232415.00

284649.00

31130.00

882770.00

6511545.00

155145.00

310310.00

294626.00

178769.00

301816.00

770043.00

47811.00

20444109.00

262321.00

527439.00

186756.00

809955.00

8731.00

759830.00

494634.00

532091.00

25432463.00
MS

23667.00

84760.00

19971.00

68678.00

232415.00

284649.00

31130.00

122677.36

2170515.00

51731.00

103436.66

98208.67

59589.67

100605.33

256681.00

15937.00

94648.65

87440.33

175813.00

62252.00

269985.00

2910.33

253276.66

164878.00

177363.66

117742.88
F

.19

.69

.16

.56

1.89

2.32

.25

\section{$22.93 * \star \star$}

.55

1.09

1.04

.63

1.06

2.71 *

.17

.74

1.49

.53

2.29

.02

2.15

1.40

1.51 
Figure 7

Drive $\mathrm{x}$ Reward $\mathrm{x}$ Complexity Interaction

For Time

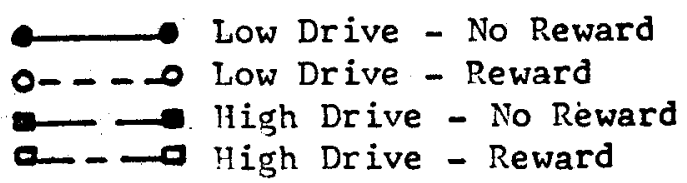

800
700
600

Time
500

In Seconds

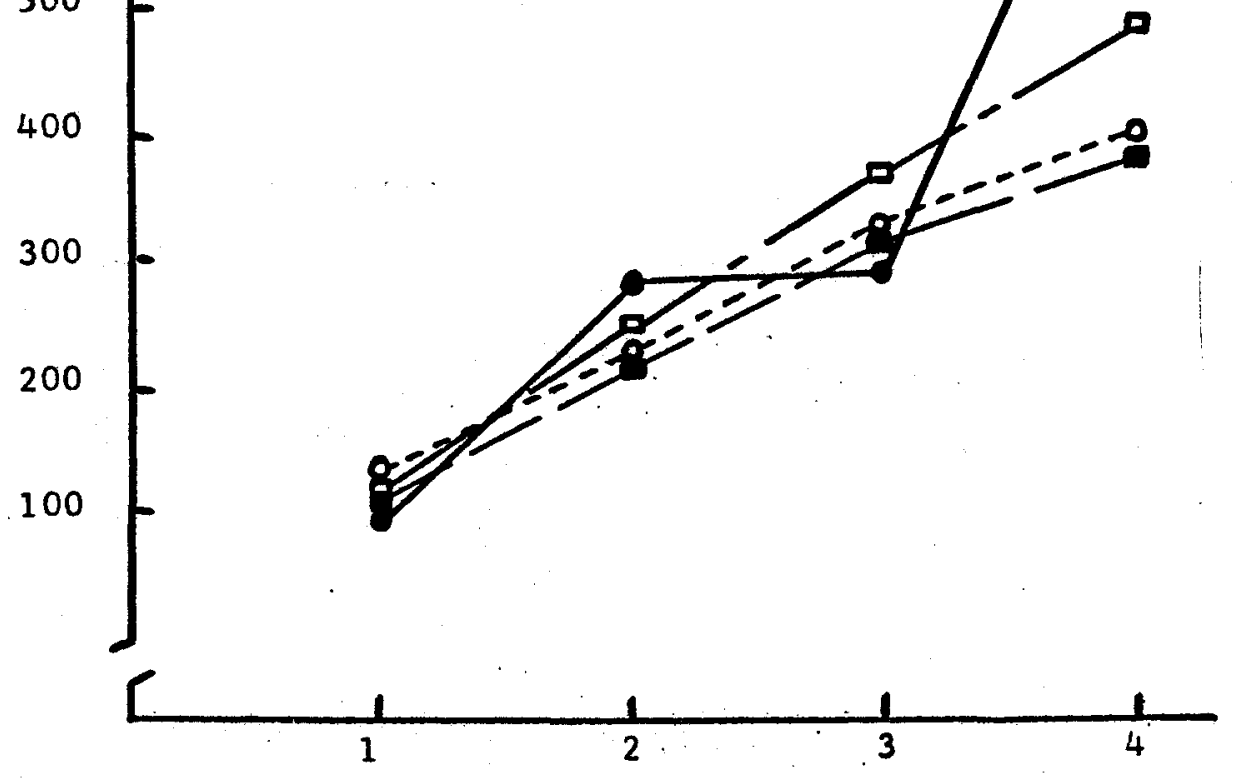

Complexity

(Number of Irrelevant Attributes) 
In the repeated measurea anlyois a giniflcant erfect occurred for complexity at the .001 level, $I(3,216)=16.94$ (see lables 20 and 22). Proble one differed algalficantly frow problem two at $p<.01$ and from problans threo and four at $p$ L.001, problas two did not differ sleniflcantly from problem three, but did differ from problen four at 2 L.001. Problea three alfered from problex four the . Ol level. As problems became conplex, perceptual inference orrors 1noreased in number. The linear trend was aignifichat at .001, $I(1,216)=50.52$. A Bignifleant triple iateraction occurrod for arive $x$ reward $x$ coaplexity, $E(3,216)=7.90, E(.001$ (seo wables 20 and 22 and Higure 8). None of the groups differed signifleantly on problems one, two and three. On problem four the low drive-no reward subjects perforwed more poorly than high drive-reward subjects ( 2 L.05) and pore poorly than the high drive-no reward and low drive-roward aubjects ( $(\mathrm{L} .001)$. The $\mathrm{hl}$ h drive-reward Eroup did not affer significantly from the high drive-no reward eubjects, but did differ frow the low drive-reward group

(e (.01). The bigh drive-no reward subjecte did not differ frop the low artve-rewar group. No effect obtained significance in the enalysin for successive probleas.

Palnar aweat index. The palmax sweat inkex score was the amount of chang 1 a millamperes froa the aubject's basal lovel. of palar swating to each IInger. The basal lovel was defined as the level evident in the third adaptational measurenent. 
Table 20

Means For Perceptual Inference

Errors With Complexity As Repeated Measure

Complexity (Irrelevant Attributes)
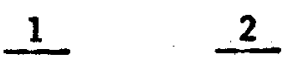

$\underline{3}$

4

Total

Non Schizophrenic

Low Drive

No Reward

.20

Reward

.40

1.00

.90

3.50

5.60

.80

1.30

.90

3.40

High Drive

No Reward

Reward

.20

.70

1.20

1.10

3.20

.10

1.20

2.00

3.60

Schizophrenic

Low Drive

No Reward

Reward

.40

1.10

.50

3.50

5.50

.30

1.70

1.20

5.20

High Drive

No Reward

Reward

.10

1.00

.80

1.10

2.60

3.00

1.20

1.70

5.60 
Means For Perceptual Inference Errors

With Successive Problems As Repeated Measure

Successive Problems

$1 \quad 2 \quad 3 \quad 4 \quad$ Total

Non Schizophrenic

Low Drive

No Reward

Reward

.70

.80

1.10

.90

1.50

2.30

5.60

.50

1.20

3.40

High Drive

No Reward

Reward

.90

.30

.30

1.20

.70
1.20

1.30

3.20

3.60

Schizophrenic

Low Drive

No Reward

Reward

1.00

1.00

2.20

1.30

5.50

.40

2.70

1.00

1.10

5.20

High Drive

No Reward

Reward

1.10

.60

.30

1.00

3.00

.60

1.40

1.80

1.80

5.60 
Table 22

Analysis of Variance For Perceptual Inference Errors With Complexity And With Successive Problems As Repeated Measures

Source

Classification (C)

Drive (D)

Reward (R)

$C \times D$

$C \times R$

$D \times R$

$C \times D \times R$

Error. (Between Subjects)

Complexity (Co)

Co $\times \mathrm{C}$

Co $\times D$

Co $\times R$

Co $\times C \times D$

Co $\times C \times R$

Co $\times \mathrm{D} \times \mathrm{R}$

Co $\times C \times D \times R$

Error (Within Subjects)

Problems (P)

$P \times C$

$P \times D$

$P \times R$

$P \times C \times D$

$P \times C \times R$

$P \times D \times R$

$P \times C \times D \times R$

Error (Within Subjects)

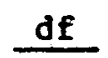

1

1

1

1

1

1

1

72

3

3

3

3

3

3

3

3

216

3

3

3

3

3

3

3

3

216

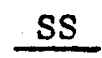

3.83

5.78

.08

.00

5.25

9.45

.03

232.32

126.31

3.43

4.13

17.58

.26

3.26

58.91

.38

536.98

17.16

5.18

3.08

16.98

7.11

5.56

16.71

7.68

671.78
MS

3.83

5.78

.08

.00

5.25

9.45

.03

3.23

42.10

1.14

1.38

5.86

.09

1.09

19.64

.13

2.49

5.72

1.73

1.03

5.66

2.37

1.85

5.57

2.56

3.11
F

1.19

1.79

.02

.00

1.63

2.93

.01

$16.94 \star \star \star$

.46

.55

2.36

.03

.44

$7.90 * \pi *$

.05

1.84

.56

.33

1.82

.76

.60

1.79

.82

$\star * \star \quad p<.001$ 
Drive $x$ Reward $x$ Complexity Interaction

For Perceptual Inference Errors

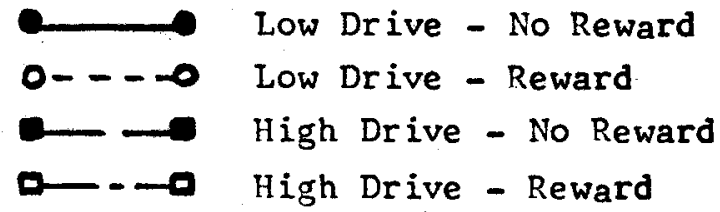

Perceptual

Inference

Errors

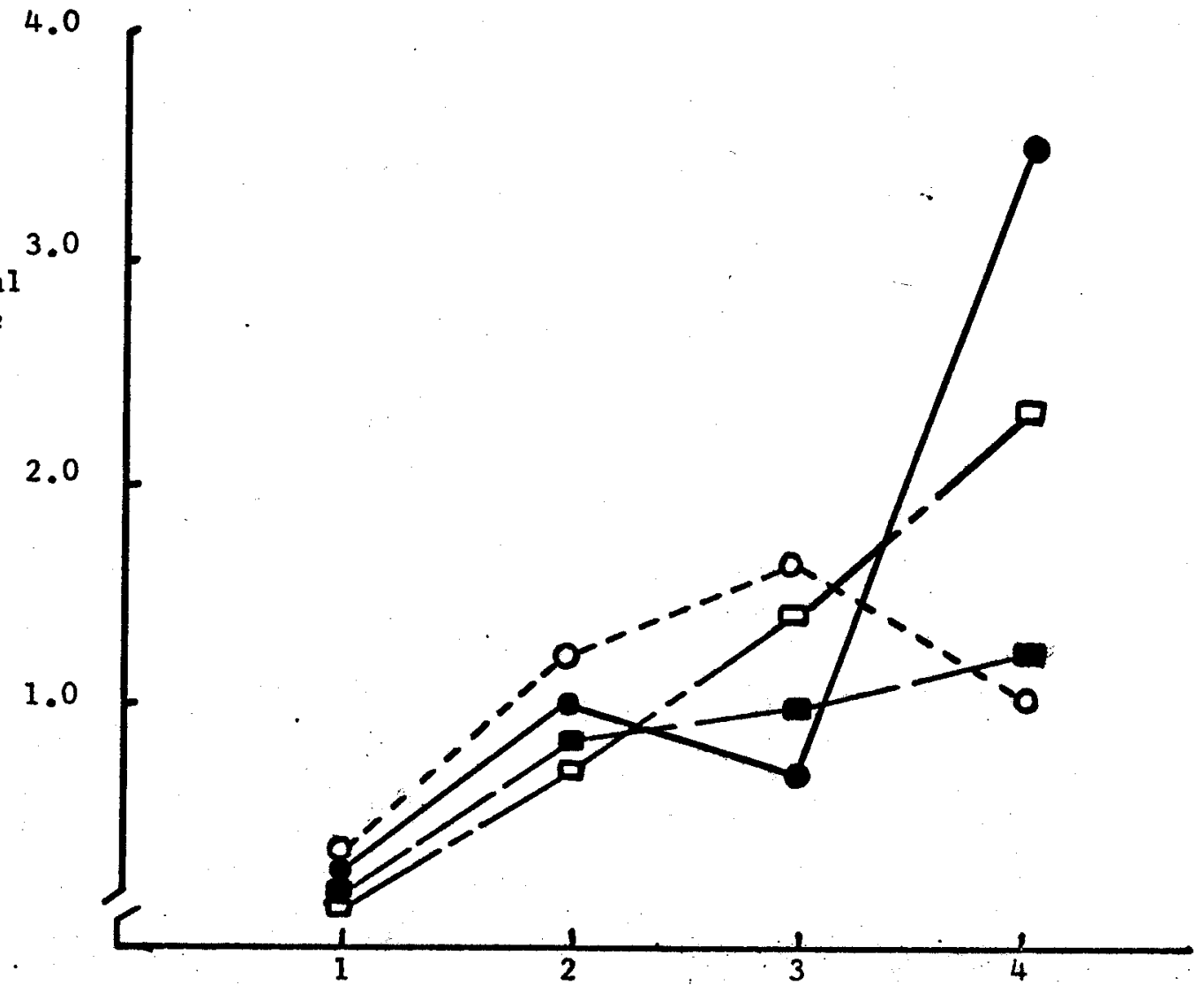

Complexity

(Number of Irrelevant Attributes) 
DSI scores wero obtalned by aubstacting each of the stiaulus rolovant prints (print four through geven) from the basal lovel print (print three) (Haywood splelberger, 1960). A constant of 50 was alded to each alferont acore to avold negstivo valuos. No signiflcant effect botween aubjecte occurrod nor ald any effect within subjeots for complexity occur (ser Tablab 23. 24 and 25). There was, howevar, a denifleant eftect for oucceselve problems, $I(3,216) \cdot 0.51,2$ L.001 (noe pables 22 and 23). The firat card prosented differod olgnitlcantly frots the seoond problex at the .01 level, while the becond problev was stgalicantig diferent from both the thind ( 2.05$)$ and the fourth (2 (.001) problone. The trond $1 \mathrm{~s}$ nolther alsnifleant

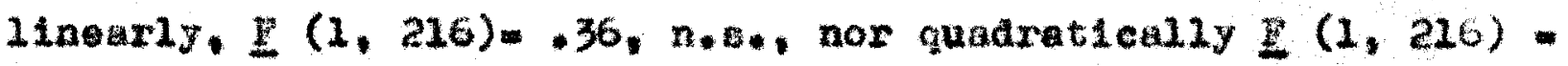
$.00, \mathrm{n} . \mathrm{B}$.

Correlationa between dependent variables

The followins correlatlons were calculated using the sums of the dependent vartablos for cach subject. In other words, the score were summed acrose problewa for each aubject and than wer correlated (aee Table 26). Focusing strategy correlated wth scanning atrategy at .37 , with untrenable hypothesed at -.45 , with chalces at -.45 , with time at -.20 . with perceptual Iaference exrors at -.35 and with palaar awen seores at -.14 . 
Table 23

Means For-Palmar Sweat Index With

Complexity As Repeated Measure

Complexity (Irrelevant Attributes)

1

$\underline{2}$

3

4

Total

Non Schizophrenic

Low Drive

No Reward

Reward

49.50
54.80

50.30

49.60

50.70

200.10

54.80

47.50

49.00

52.20

203.50

High Drive

No Reward

Reward

51.30

54.40

49.90

46.10

50.30

50.70

201.70

50.30

200.10

Schizophrenic

Low Drive

No Reward

Reward

51.40

54.90

50.20

50.60

207.10

47.30

49.80

48.10

193.50

High Drive

No Reward

47.20

46.10

46.80

49.10

189.20

Reward

51.60

55.70

52.20

51.80

211.30 
Table 24

Means For Palmar Sweat Index With

Successive Problems As Repeated Measure

Successive Problems

1

2

3

4

Total

Non Schizophrenic

Low Drive

No Reward

Reward

50.80

53.70

47.00

48.60

200.10

49.90

50.70

51.00

203.50

High Drive

No Reward

Reward

49.40

55.50

51.50

45.30

201.70

49.50

52.00

50.30

48.30

200.10

Schizophrenic

Low Drive.

No Reward

52.20

54.80

52.00

48.10

207.10

Reward

47.60

47.20

47.60

193.50

High Drive

No Reward

47.10

49.00

47.10

46.00

189.20

Reward

50.90

55.30

54.30

50.80

211.30 
Table 25

Analys is of Variance For Palmar Sweat Index With Complexity And With Successive Problems As Repeated Measures

Source

Classification (C)

Drive (D)

Reward (R)

$C \times D$

$C \times R$

$D \times R$

$C \times D \times R$

Error (Between Subjects)

Complexity (Co)

Co $x \mathrm{C}$

Co $\times$ D

Co $\times R$

Co $\times C \times D$

Co $\times C \times R$

Co $\times$ D $\times R$

Co $\times C \times D \times R$

Error (Within Subjects)

Problems (P)

$P \times C$

$P \times D$

$P \times R$

$P \times C \times D$

$P \times C \times R$

$P \times D \times R$

$P \times C \times D \times R$

Error (Within Subjects)

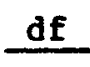

\section{1}

1

1

1

1

1

1

72

3

3

3

3

3

3

3

3

216

\section{3}

3

3

3

3

3

3

3

216

\section{SS}

$$
5.75
$$

1.13

33.13

.95

14.10

294.57

517.56

13479.38

110.30

75.89

64.41

49.31

229.84

216.79

102.71

189.68

8252.32

929.50

10.94

94.81

126.81

81.89

65.44

8.51

106.63

7866.72
MS

$$
5.75
$$

1.13

33.13

.95

14.10

294.57

517.56

187.21

36.77

25.30

21.47

16.43

76.61

72.26

34.24

63.23

38.20

309.83

3.65

31.60

42.27

27.30

21.81

2.84

35.54

36.42
$\underline{\mathbf{F}}$

.03

.01

.18

.01

.08

1.57

2.76

.96

.66

.56

.43

2.00

1.89

.90

1.65

$8.51 \star \star \star$

.10

.87

1.16

.75

.60

.08

.98 
Table 26

Correlations of Dependent Variables

Focusing

Scanning

Untenable Hypothes is

Choices

Time

Perceptual Inference Errors
Perceptual Palmar

Untenable

Scanning Hypothes is

.37

$-.45$

$-.45$

$-.26$

$-.55$

$-.49$

$-.64$

$-.17$

.88

.53

.85

.15

.55

.86

.15

.55

.18

.12 
Scanning stratesy correlated with untenable bypotheses at -.56. with cholcen at -.78 , with tine at -.49 , with percuptual Inforenco orrors at -.64 , and win paltar sweat soures at -.17 . Untenable hypotheses correlated with cholces at .88, with time at .53, with perceptual Inference errors at . 35 , and with the palaar swost scores at .15 . Cholces correlated with tine at . 55 , with werceptual infersneo errors at .86 , and with palmar sweat scores at .15. Tlue correlated with perceptual Inference errors at .55 and with the paluar eweat index at . 18 . Perceptual 1nference exrors correlated with the palmar aweat Index at .12.

Sumary of results

A $2 \times 2 \times 2 \times 4$ repeated pasures factorial deelgn was used. Two analysea of varlance were done for each dependent variable, one for the complexity of problan and one for successive problems as repeated mearures. For focusing strategy, a complexity effect indleated that as problens becane tore complex, less focusing occurred. For scanning stratoby, artve $x$ reward Interaction occurred wherein the high arive group perforaed are poorly under the reward condition. Aleo, when analyzing scanning for complexity, a complexity effect showed that, as problems increace in complexity, lesa scanning strategy is employed. A triple interaction, drive $x$ roward $x$ complexity, occurred for scaning. with differences between groups belng alinifloant only on the nost complex task. For untenable 
bypotheses, an effoct showed that, as complexity increased more untenable hypotheas wert aubritted, Also, a reward $x$ conplaxity effect demonstrated that, although no differences betwe the reward groups occurred on the $16 \mathrm{as}$ complex problens, aubjecte recelving reward on the most complex problen perforned better than those recelving no reward. A arive $x$ reward $x$ complexity interaction for untenable hypotheaen revealed Intergroup differences only on the nost complex task. For choloes, a complexity effect revealod that, as complexity 1ncreased, eubjecte made moxe card cholces. A drive $x$ reward $x$ complexity interaction also occurred for cholces, wherein Bigniflcant intergroup alfferences occurred only on the most complex takk. Also, an effect for succesatve problons was evldent, showint that as problexs were prosented succeasively, wore cholces were made. For time, en effect denonstrated that, as complexity increasou, time also inoroased. A arivex reward $x$ complexity interaction occurred for time with intergroup differences only on the nost complex task. For perceptual Inference errors, an effect revealed that complexity Increased, more perceptual inference exrors occurred. A drive $x$ reward $x$ complexity effect obtalned with olgnificant intergroup afferences only on the most complex problew. For the pelmar oweat Index, a sifnificant effect for successtvo problems ocourred, showling that a problews were presented successively. 
an Increase on the firat problem and then consigtont decrease In pelana weating occurred.

The priarary findings wore: (1.) a drivo $x$ reward intaraction for acanning; (2.) a complexity effect for all dependent varlables except the palnar sweat index; (3.) reward $x$ complexity offect for untenable hypotheses (4.) a drive $x$ roward $x$ complexity effect for canning. untenable hypotheses, cholces, time and percoptual lafkrence errora; (5.) a successive problens effect for cholcest and $(6$.$) an effect for successive$ problems for the palmar weat indox. Correlatione between dependent var1ables were generally $\mathrm{blgh}$, except for correlationa with the palmax swent index. 
Chapter V. Discusaton

This study is one of the firet to utilize Brunex, Goodnow and Austin's (1956) concept formation task with a psychiatric population in the inveatigation of schizophrenic thought processes. The Bruner task has principally been uned with students. The task was chosen for this study because prior research with schizophronic thinking, presented in the introduction, bas generally made use of tasks possessing an affective component in the stimulus material itself. This ooncept forwation task presente essentially nonaffectually arousing stiauli and taps the wore formal, structured thought processes. Since the tagke are not intringlcally affectually arousing and contain only geonetrie designs, the tesks seem h1ghly appropriate to tap schizophrenics" conceptual abilities. This more theoretiol point of view was substantiated by the Interest and excoptionally long attention span exhibited by the schizophrentc gubjects.

The bypotheses for this study were derived priaarily from the theories of Goldstaln, Cameron, and hednlck. These three theoreticlans were considered by thil researcher to have taken positions which were not entirely accurate. 
The coapeting hypotheees raflect the easentlal differances of the three theoreticians and aloo reflect this expurineater"s viaw. Hypothoses I (Cameron), II (Goldatein) and III (Mednick) predict alferences between sohlzophralos and non-achizophrentes. Hyothegle IV (thle researcher) sugeste thet if drive levela are controlled for achizophrenic and non-sch1zophrenie groups, there wil bo no sigalficant afferm ences in the conept formation proceases evident on the Bruner, Ooodnow and Austin thek between schizophrenles and non-aohi zophrontos.

At flret glance, it would appear that the intent of this project 18 to prove the null hypothosis. The intent Inatead lo to devonstrate that the theorles of coldstein, Cameron and hodnlek are not suffictent to acoount for the performance of schizophrenles and non-schizophrenice when drive levels are controlled and also when formal, conceptual taak 1a omployed. The hypotheges then nust not be avaluated Individually in terms of the null bypothesis, but rather tho four primary hypotheses wust be considered as an integrated whole. The nature of the cxperimental design allows this integration to occur shen such a conceptual integration is accomplighed, it is eviant that the pltfall of atteapting to prove the null hypotheses ia not alrectly applicable to this atudy. 
Before discusaing the signifieant efecta, it ghoula be noted that the perceptual inference error scoring was silghtly diferent from Cah111 and Hovland (1960). By inspecting tho dats in this study, it was found that subjects froquentig made orrore Ineonsistent with information avellable on the two previous instancev. Two such succeastve exrors were scored as perceptual Inference errors. Ihl procedure contrasted with Cabl11 and tiovland (1960) who defined auch errors as arising from only the ene previou instunce. It seeat that an inpatient psychlatrle population perhaps experience aore memory alficul tes then a non-peyehiatrie population because of 1ntrusive anxiety. thereforo, the dopendent variable was evolved Into aro preclae neasure by lncluding two, rather then only one, perceptual inference error.

Maln effects

Cameron would expect main effoct for clasfiflcation inco schizophrentc and non-echizophronic. he belioved that schizophrentos should perfor moxo poorly than non-achlzophrentos because the schizophrenic over-generallzes and over-1noludes nore.(Ilypotheass IA). Yet, the results of this study demonatrate that on thia formal concoptual task, thero 1 no main effect for classification. 
Stnce the conxonly acoepted notion is that the vebizophrenle'a poor conceptual perforance resulta froen his Inablilty to focua on the test anterial and to avola belag distracted by 1 rrelevant stimul1, the flnding of this study that the performance of schizophrenic and non-schizophrentc paychiatric patients does not differ elgnificantly on conceptual takk is Indeed alarming. The implication of this finding 18 that researchers and ellalclans moy possibly have ben unable to tap those conceptual abllities avallable to the achizophrentc. Hy the nature of the bruner tak, the cohizophrentch ablilty to lntegrate and to focus upon a mass of meterial now becomes evident. The lack of a gnilicant aln effect for claselfleation 10 supported by heoauthran and Moran"a (1955) (1nding that ohronic paranold wehleophrontca ata not affer in their concoptual ab111ty from non-psychlatric controla. HeGaughran and Moran oaphasized that the schizophronic defleit wo the inability to communieate socially. It seeas highly relevant that the sohizophrenic cognitive deficit must also be related, to the nature of the task involved. To 1ngure the schizophroulc's meximal performance, the atimuli should probably be non-affectually arousing in nature, thereby 11mitias the number of latosyneratic asaolations avaliable to the echieophrenic. Furthor reveorch is eertalnig sugbested in evaluating the nature of the etiaulus and the tak Itese along the continuun of non-affectual to affectualiy etiaulating 
ataterial. It would be expected that the achizophrenic'a conceptual abilities wuld alainish as the tak becano more and more ationally arouaing.

The siallarity of achizophronics and non-schizophrentes in this study ald be accounted for by balancing of the groupe on the basis of arive levels, In adition to the non-affectual content of the task. In previous studies it is falriy evident that the subject groupe ald not poseese olaliar axive levels. thereby contributing to the signifleant differences found between schlzophrentc and non-schizophrenie behavior.

Hednick would prediet aignificant aln effect in this study for axive (Mednick, 2958). He belleved that, because high arive fosters reator generalization in regponding to irrelevant cues, high drive subjests should have nore alfficulty in concopt formation than low arive eubjects (Hypothesis IIIA). Yet there was no signiflcant main effect for arive in this otudy. This findiag suggeats possibly that Mednick's formulation io Ineccurate regarding wore formal concoptual tasks. H121 (1960) on the other hand belleved that high arlve should atreagthen relevant reaponses in anar directly proportional to 1rrelevant responses. H111, therefore, would have expected no main effect fox axlve (Hypothesis IXIAI). H111's expectation was upported by the data. It mat be noted onee again that conIrmstion of auch an expectation does not prove it, but only ouggeste possible eredenee. 
There were elgnifleant anin effects within the repeated measuree factor for both complexity and successive problome. A Ilnear complexity affect obtalned for all the dependent varlables, except for the paluar wwat index. Buch a consistent effect occurred, beceuse, as problens beoane nore cosplex and more alffioult, tho process of formirg conceptes and of oognitively dealing with tho takk boese nore difelcult. Nono of the hypothese was direotiy concerned with this finding. It should be noted that for ecenning etrategy and untenable hypotbeses, the number of posatble hypotheses lacreases as the complexity level increases. For examplo, for one relevant attribute, thres possible hypotheses exlats for two relevant attributes, alx hypotheses; ror three, ten bypotheses, and for four relevant attributes. 15 poselble hypotheses exist.

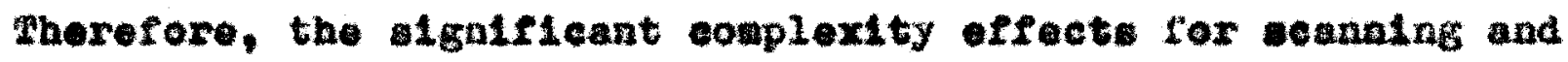
untenable hypotheses include and light be accounted for by the Ereater number of hypotheaes for lnereasting levels of complexity. However, a complexity offect existe for the numer of card oard choloes, Indloating that the greater number of hypotheses canmot singulaxly account for the complexity affecta for acanning and untenable hypotheses. Wo consiotent conplexity in the dependent vamiables related to concept formation 1 consonant wt the findings of Batig and bourne (1961). The muber of trials to oriterion in a concept Indentifioation tak Increaeed with the number of irrelevant 
dimensione; 10., concept formution was more afficult with are 1rrelevant dimenelons (Battie and Bourne, 1961). Othor atudiea Bup orting complexity effect are Bourne (1957). Bourne and Fendieton (1958), and bourne and Naygood (1959).

rather peculiar effect for cucesalve problets occurred when analyzing the cholect dopendent variable. The nuaber of cari choicos incroased with olgnifloant linearity as problews woxe preoented. The contrary is expected if learaing is taking plsce. That 1s, if lobring is occurring, thon fower cards shoula be chosen as problens are prosented. Probably a fatigue of cect is operating the would azuse subjects to be low cutioug in thelp cand cholces, oven though the examinex instructed them to choose as fow oaras as posalble. If a fatifue effoct is operating, a successive problems effect should occur for tstue. but thexe in no such signifloant efrect. Therefore. 1 can be stated that partial fatioue effect 1 s occurring, which allows these peychiatric abjects to neglect the instructions and to bo loes diecriminative in choosing cards, but wilch does not augment the tias apant on each problew.

A succesalve probles effect alao obtalned for PSI scores. The meana were followa f1ret problea $=49.68$; second problew $=52.91$; thixd problem $=50.01$; fourth problen -48.21. The f1rst problen does not fit into the otherw1se 11near trend. since when that problem was presented and the print was taken. 
the subject did not understand the nature of the task. On aubsequent problans. oubjects were fully aware of the nature of the task. The negative Ilarar trend for the socond, third and fourth succeselve problow reprosents physiologleal adaptational efrect.

\section{pirat order interactiona}

A slgnifleant arive $x$ reward interaction obtained for scanning atrategy. The 1ntexaction was accounted for by the debliltated performance of high drive subjecte under the reward condition. The decreased performance for high drive subjocts la expected by arousal theory. Arousal theory wuggests that there 1. a curvilinear relationship (an inverted 0 function) between bohavioral efflelency and asure of aroueal (Cofor \& Appley. 1965). To expect high arive subjects to perform more poorly with increased motivation necesaarily places them on the $\mathrm{x}$ ght hand half of the motivational continuum and of the laverted $U$. Let us claxify how high drive and low drive ware defined in this stuay.

An Important dfference existe in the operationel dofinition of high and low drivo for paychiate lopatianto in tbis study and the operational dafinition of bigh and low dxivo for a non-clinical population. Low drive 1 defined as those WAS cores falling at 24 and below, whereas low drive for a non-elinical population, usually collose students in 


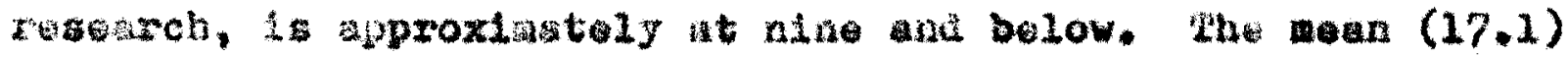
for poychlatslo low dxto aubjoco then falle at approximately the so porcantlo for non-clinlcal abjocts. High arive la

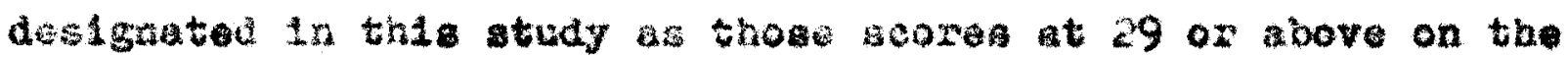

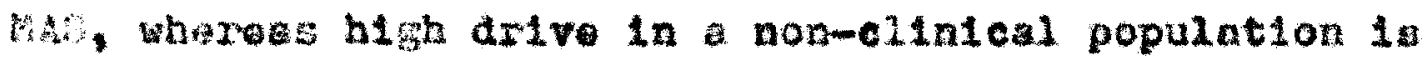
approximately at 19 and above. The moan (34.6) for thoso paychlatrie high arive cubjects fallo at approxilately the 98 porcont1le for non-clinical subjects. Therefore, about 75 peroent of the eubjects in tais study may bo consldered to be bit drive subjeots acooralug to non-ellaioal norne. The hish drive eubjects in this study fell at the upper end of the motivational contlauum, perfomed more poorly undex reward conditions, and thus colnclded with the predictione of arousal theory for the drive $x$ reward interation for soaning

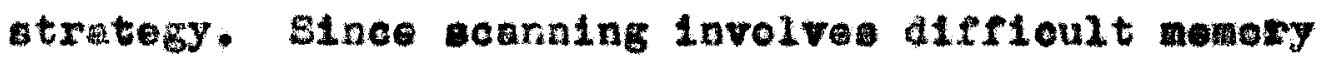
requirenento, the debli1tation of the high drive group recelving rewad apporently rofloote docroace in the ab111ty of high drtve abjects to utilize their monory capactien under conditions of rewand of increased motivation.

Pto othor signiflcant firat order interaction was reward $x$ cosploxity intoraction for untenable hypotheses. Whe interaction was accounted for by the reurd group perforning better on the aost complex task than the no reward group, while the other lovels of complexity did not contributo to aay elgniflcant alfferences. Uaing conceptual model for arousal 
ainllar to the model desaribed above, the inproved perfoxwance of the reward group was cartalaly unexpected. since aubjects in this atudy fall princlpally on the upper half of the lnverted $U$ continuua, any iacrease in motivation should deblittate and not entance perforance. This findiag certainly neads to bo Invostigatod further. It is possible that the aubjective value of reward on this most complox task is minial when considering 1t across abjects and arive. phe subject may tend to value the oogaltive challenge of the tak more than the subjective value of the rowerd. By subjectively devaluing the reward, he concomitantly inlulues his motivation, thereby allowing himalf to pexfora ore effectively. Since untenable hypothecea Involvo a meny component, the docreased motivation probably reflects an enhence menory capac1ty. None of the hypotheses in the ctudy directiy relate to thic interection between reward and complexity.

Wany of the hypotheses were coneerned with firat ordex Interaction which never achived eignifieance. Caseron's 1dea that schlzophrenics confroated with a cuplex problea would function more poorly than ehisophrenice confronted with alaple problen (Hypotheala IB) because of overincluaton and overgeneralization, could be domonstated in a clasplfication $x$ complexity interaction. Goldstein would predict the same interaction sine the schizophrenic apparentiy thinks in conerete

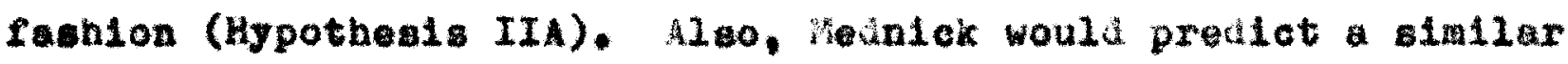


classification $x$ complexity intertction, sluce achizophrentes ahould posseas wider ceneralization sradient and rowond to more Irrelevant cues than non-achlzophrenics (Hypotheses IIICI and IIIC2). No claseifleation $x$ complexity interaction achieved elgnifloance in this otudy. Again, ouch results do not disprove the hypotheses, but do seem to land some doubt as to their accuracy and applicabli1ty to the aubjects and the taak employed, partioularly because of the tight experinental methodology ut1.1.zed in this study.

Goldsteln and Medici would have predicted that clasalfication $x$ arive effect would obtain. Goldatein would season: conrete thinking results from arolding catastrophio anxiety; some achizophrentcs have antalzed thelr anxlety by thinking in concrete fashion (low drive achizophrenics); othor achizophrenics have not mintized their anxiety effectively (high drive sehizophrentes) since low arive achizophrentes thlnk in a concrete fashion, they should perform more poorly on conceptual tasks than high drive schizophrentes. Mednick would reason: high arive chlzophrenicg have sore irrelovant response tendencies because of higher drive contributing to broeder generallation gradient; low drive schlzophrenles and non-schiophrantea have fewer irrelevant rowonge tendencias because of lower arive; therefore, drive and classiflction ahoula interact significantiy. Yet, not such oflect obtained algniflcance in this study. 
Hinally, Mednick would have postulated drive $x$ complexity effect (Hypothesis IIIB). High arive should elle1t more irrelevant responeo tendeneles than low dxire. On complex terks more Irrelevant cues are avallable and should then be elleltod by high rather than by low arlve. Agaln, there was no aignificant arive $x$ complexity efrect in thic study.

The three interactions hypothesized in the lest three paragraps (claselfication $x$ complexity, classification $x$ drive, and dxive $x$ complexity) all seem to essume that drive levels in tehizophrenic and in non-sohizophrento disordere cannot be equated. It is this writer's contention that none of these tbre intersetions obtained signiflcance in this study because drive levels were equated for both claselfication groups. In thie nanner it was possible to prevent the confound between drive and sobizophrenia, whioh may have been clouding the porceptions of the three theoretielans.

Second order Interdetions

A ratber conalstent interaction, drtve $x$ reward $x$ coraplexity, obtalned for scanning, untenable bypotheses, chotces, than and perceptual inferonce exrors. Subject groups significantly differed only on tho most complex problens. Aroustl theory was ut1lized in interpreting the results. An inverted $U$ continuun for motivation (low to $\mathrm{hlgh}$ ) was placed on the $x$-axis and performance on the $y$-axis (poor to good). The subjects within this study fall prinelpaily within the 
fiftleth to ninety-ainth percentilo of non-psychiatric WAS scores. Therefore, the expected rank order of performance fron good to bad for subject groups within the triple interaction was: Low drivo-no reward; low drive-reward; hlgh drivo-no reward; hlgh drtve-reward. The expected order is based on arousal theory: Increasing drive lovelo in the upper balt of the motivational continuum yleld decreasing performance. Untenable bypotheses, cholces, time and percaptual inference orrors seam to follow a conelatent pattern on the most complex problem. Low drive-roward, high drive-no rowari and high drive-rovard groups usually desonstrate no alfnifioant alfferences or aro ordered in the manner expectad by arousal thoory. The 10w arlve-no revard sroup seens to defy expectations, alnce it consiatently performa worke than all four groups. High drivoreward subjects are always rank ordered juat above the low dr1ve-no roward group. It is extremely iaportent to note that the non-verbal intelligenee coras sbowed that the low drive-no rewand group goseessed algniflcantiy $108 \mathrm{~s}$ non-verbal

Intelligence thao the bigh drive-reward group (e C.05). Fho SRA non-rerbal task 18 essent1al1y concept formation tak in which eerlas of flve pletures or diagrame sre presented. One of the five plotures aut be dealgnated as not belonglng with the other

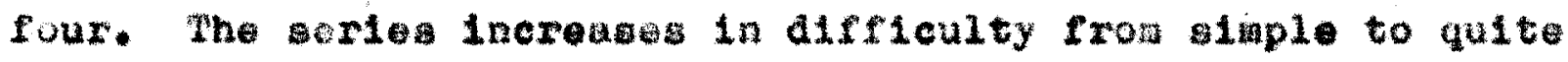
complex problems. Since the low driveno reward group in $10 \mathrm{~s}$ bright on nor-verbal intaligence. the reveras of the low 
drivo-no roward croup fron the prediotloas of arousal theory could be attributed to the group fower of non-verbal inteli1sence; i.e., poorer conoeptual ability. the wean non-verbal 1nte111 gence score is lower than all other cell meane, but 18 signifleantly alferent only from the high drive-reward croup. A confound then appere to exiet for thic triple intaraotion, ana it ocours even though aubjects were randouly assigned to rowand eroups.

The rank order of group mans for the arive $x$ roward $x$ complexity interaotion for caning atratogy 1 silighty different from the othar dependent variables. The posttions of the high drivo-no reward and low drlve-reward grops aro reversed, so that high ariva-no ravard groupe perfore better then the low dme-no reward group at the .05 level. For ecenning, poesibly the pexformance of low drive aubjecte 18 so. anhaneed by the inoentive of reward that the motivational lovel attalned with reward 1 higher than the motivational lovel or bigh drivo-no reward cubjects. Slnee this flndins ocours only for conning the enhaneed perfomence 1, probably function of Laproved memory. Thie probles should oertalaly be inveetlgated moxe peafically to clarlfy the notions presented.

Coments

No signiflcant differences in PGI acores wore noted for non-zchlzophronle and sohlzophrenle groups, for high and low 
artve groups, nor for any interection betwen the two. These similarities between groups aight be confound of the use of phenothiazines for the echlzophrenic group (a $\angle .05)$. The intent of the phenothiazne preseription is to mininise excessive autonomic arousal and to sllow subjecta to utilize their cogaitive abilitiea. Previous atudio on concept foration taska with paychiatric subjeots have gonorally not reported data regeraling gedications. pherefore, studes reporting differences between schizophrentes and non-schizophrentcs were cubject to the same hedication confound as was this study. It is necessary then to investigate the lsoue of axousal in psychlatric patients In more vell-controlled drug tudy.

It is curloue that focueing did not delineate any signifleant differences betwen groups. Perbaps focusing tapa the more fomal loglcal capacitias withln subjecta. Lcanink on the other band, seens to tap the menory functions in subjects. If this differentiation between focuaing and scanning 15 cecepted, then the difference between arive groups under reward and no rowar conditione can be attributed to variab111ty in the capecty to at111ze memory. rather than in the abl11ty to excorciao formal logle.

The correlation between foeusing and scanning in this study was notably lower then previous studies with a colles student popuzation, as in Laughila (1966). The correlationg between the othex dependent variablec wero alao notably different. 
These differences way readily be accounted for by the different natures of a college student and paychlatric population. Perhaps within the psychistric population, there is a sreater intrustion of anxiety whicb would debilitute effective matory functioniag, while in the student sample, a lower level of anxlaty would be present.

An leplioation for the treatment of achizophrenica is sugested. Since this tudy reveals that schizophrentes can function cognitively in almilar fushion to non-schizophrentes on a formal conceptual task, it ay be advantageous to encouraze schizophrenles to perform on such takks part of treataent. When success on such tasks occurs, it is expectid that some increase in self-estere and potivation to partiolpate in the therapeutle program nay oceur. The tasks ay then be gradually increased along the continuum of non-afrective to affectively arousing taks. Perhape ene generalization may oceur in whioh the aucese in dealing with non-affectual cognitive taks may be experienced in dealing with affectually arousing taska,

The novelty of this reaturch project should be enphasized. The 11 terature doen not reveal any study utilizing Bruner, Goodnow, and Austin's (1956) concept formation task with psychiatric population. The 11 terature slso does not contain any study to date on ochizophrenic thinking in which a schizophrenio and a control group have been balanced for drive 1evels. Nowhere could study be found which investigated the 
effecta of non-verbal roward on a concopt formation task. Nowhere could studies bo found whon attanpted to rel

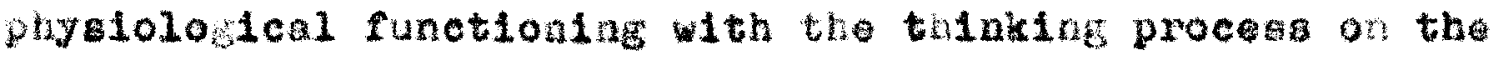
concept foration teak used in this study. 
Chapter VI. Summary

A $2 \times 2 \times 2 \times 4$ repeated measures factorial design was used with the following vartables: (1) Classification (non-schizophrenic or schizophrenic inpatients); (2) Drive (low or high); (3) Reward (no or yes); (4) Problems (one, two, three or four irrolevant attributes on a concept formation task). Repeated measures were analysed for both the complexity of problems and for the successive presentation of problems. The dependent variables included focusing strategy, scanning strategy, untenable hypotheses, card choices, time, perceptual inference errors, and palmar sweat index. For scanning strategy, high drive subjects performed more poorly under reward than non-reward conditions. As problems became more complex, subjects had more difflculty performing; this was a linear trend for all dependent variables except for the paimar sweat index. For untenable hypotheses, subjects receiving reward performed better than nonreward subjects, but only on the most complex task. A drive $x$ reward $x$ complexity elfect revealed rather consistently that only on the most complex task, groups were rank ordered as foilows: low drive-rewajd performed best; then high drive-no reward; then high drive-reward; then low drive-no reward. 
As problens were presonted auccesstvely, more cholces occurred. An adoptetionel effect occurred for the palmer swest index for successive problems. Correlationa between cepentent variables were generally bigh except for those with the palaer sweat index. Eesults were interpreted primerily in terms of arousal theory and the exceptionaliy high lovel of drive of the paychiatric subjecte. Populer theortes of schizophrenia were not supported, though not disproven. 
References

Batt1g, S. and Bourne, L.E. Jr. Coneept ldentifleation as function of intra- and intem-dineneional rariability. Journal of Experimental Paxcholony, 1961, 61, 329-333.

Bourno, I. Ir. Ir. Effeets of delay of information feedback and tabk couplexity on the laentifleation of conceptr. Journal of Experimental Paycholom. 1957. 24. 201-207.

Bourn, L.E. Jr. and Baygood, R.C. The role of stimulus redundancy in concept Identification. Journal of Expertmentel Earcholor, 1959, $58,232-238$.

Bourne. I.E. Jr. and Pendleton. F. Coneept Identifleation as a function of completeneas and probsblilty of information feedback. Journal of Experlmental Eaycholost, 1958,56. 413-419.

Broen, W. B. Fesponse disorganization and breadth of observation In schizophronia. Esrchologlegl Beview, 1966, 3, 579-585.

Brumer, J.S., Goodnow, J.J. and Aust1n, G.A. A Studr of Ihinking: Now York: W1 ley, 1956.

Brutten, E.J. Palwar aweat investigation of disfluency and expectancy adaptation. Journal of Speech and Hearlar Besearch, $1963,6,40-48$.

Bullook, D.H. and Brunt, H.Y. The teatabllity of paychiatrie patiente in an operant conditioning situation. Parcholorical Record. $1959,9.165-170$.

Buskirk, C.U. Performance on coaplex reasoning taska as e function of anxiety. Joumal of Abnorarl and Soclal Psrohologx, 1961, 62, 201-209.

Buss, A.H. and Danlell, E. D. Stleulua generalization and schizophrenta. Joumal of Abnornal Paycheloxx, 1967, 22,50-53. 
Cahl11. H.E. and Hovland, C.I. The role of menory in the acquisition of concepts. Journal of dxnerlinential Porcholosy, 1960, $29,137-144$.

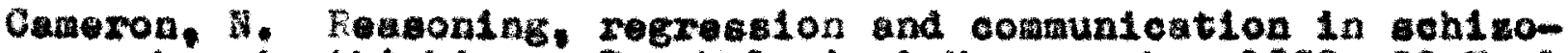
phrenic thinking. Psteholorical Monorgangs, 1938, 50. Wo.1.

Cameron, N. Experimental analysis of schizophrenic thinking. In J.S. Rasanin (Ed.) Lansugae and Thourht in

echlzophrente. Berkeley: 1955, 50-64.

Cameron, H. and Magarot, A. Bohavior Pathology. Boston: Houghton-H1fel1n, 1951.

Campbell, D.T. Princlales About Drlre. Unpubliahed Manuecript. Northwetern university, 1962.

Cavanaugh, D.K. Inprovenent in the performance of cohlsophrentor on concopt foxmation tasks as a function of potivational change. Journal of Abnomal and Boclal Psrohologx, $1950,57,8-12$.

Chapan, L.J. The role or type of distractor in the "conerete" conceptual performence of schizophrenice. Journal of Bernonal1tx, 1956, 25, 130m141.

Chapaan, L.J. A reinterpretation of some pathological disturm bances in conoeptual broadth. Journel of Abroxal and Soclal Porebolory, 1961, 62, 514-519.

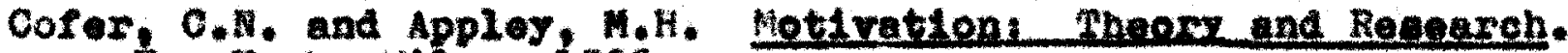
New York: hlley. 1966.

Cohen, B.D. Motivation and porformance in schizophrenia. Journal of Abnormal and soetal Paxoholary, 1956. 22.186 190.

Covdon, R.C. Problem solving in schicophrentes as function of mot1vation. Fexchologlcal Reporte, 1962, 10, 627-633.

Dominowakl. R. Role of momory in concept learning. Paychologloal Bulletin. 1955.63. 271-280.

Garmezy. N. Stimulus differentiation by schizophrenic and normal subjects under conditions of rewerd and punishment. Journal of Perronal1tx, 1952, 21, 253-276. 
Glucksbery. S. The influence of strength of drive on functional flxedness and perceptual recognition. Journal of Experimental Psychologr, 1962, 63, 36-41.

Glucksberg, S. Problen solving: response competition and the Influence of drive. Paychologleal Repotts, 1964, 15. 939-942.

Goldstein, K. Methodological approach to the study of sehizophrente disorder. In J.S. Kesenin (Bd.) Language and Thought in Bchizophrenia. Berkeley: University of California. 1944.

Goldsteln, K. Human Nature in the Light of Paychopatholosy. Cambridge: Harvard UnIvergity Press, 1947.

Goldstein, K. Concerning the concreteness in schizophrenia. Journal of Abnornal and Soctal Psychology. 1959, 59. 146-148.

Hartlage, L.C. Effects of Chlorpromazine on learning. Psychological Bulletin, 1965, 64, 235-245.

Haywood, H. C. Differential effects of delayed auditoxy feedback upon palnar sweating, heart rate, and pulse pressure. Journal of Speech and Hearlnz Research. 1963, 6, 181-186.

Haywood, H. C. and Splelberger, C. D. Palmar sweating as a function of differences in manifest anxiety. Journal of Personallty and Boolal Psychology, 1966, 3, 105-105.

Heidbredder, $\mathrm{E}$. The attainment of concepts. Journal of Psychologx, 1946, 35, 173-223.

Hill, W.F. Learning theory and the acquisition of values. Psycholosical Review, 1960, 67, 317-331.

Hull, C.I. Principles of Behavior. New York: AppletonCentury-Crofts, 1943 .

Hunt, J. MeV, and Cofer, C.N. In J. MeV. Hunt (Ed.) Personality and the Behavior Disorders. New York: Monald, 1944.

Jasper, H.H. Recent advances in our understanding of aecending activities of the reticular system. In $\mathrm{H}, \mathrm{H}$. Jasper et al (Eds.), Reticular Formation of the Brain. London: Churchil1, 1958. 
Johannsen, W.J. Motivation in schizophrento performence: a revlow. Parchologloal Reports, 1964, 15, 839m890.

Kllberis. J. The differentlal effects on non-verbal and verbal rewards in the modification of verbal behavior of achizophrenios and nornal subjecte. Dlsestation Abstracts. $1962,23,1074$.

KInE, 0.P., Armitge, S.G. and M1ton, J.F. A therapout1e appronch to schizophrenics of extrease pathology: an operant interpersonal method. Journal of Abnornal and Boclal PBxchologr, 1960, 61, 276-266.

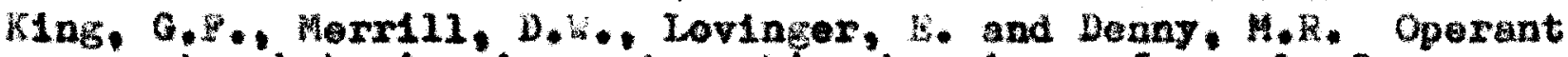
notor behavior in acute schizophrentes. Journal of Pergonal1ty, $1957,25,327-326$.

Lang, P.J. and Buss, A.H. Paychologleal deficit in schinophrenla. II. Interference and activation. Journal of Abnormal Percholosy, 1965, 20,77-106.

Laughiln, P.R. Selection strategles in concept attalment as a function of number of relevent problen attributes. Joumal of Experigental Estchologx, 1966, 21.773-776.

Hacbonald, w. snd Sheohan, J.G. Responses of achizophrentos to different ineentives. Peroholoficel Reporte, 1962, 11. $211-217$.

McGhie. A. Psychologloal studiea of ochisophrenta. Britin Jourat of Modical Psycholory, 1966, 39, 281-288.

Maltaman. I. Motivation and the alrection of thinking. Perchologleal Bullet1n, 1962, 52, 457-467.

odnlak. H.T. and Linaslay, O.R. Some clinical correlates of operant behavior. Jourual of Abnomul and Goclal Poycholosy, 1958, 27, 13-16.

Mednick, S.A. A learning treory approech to research in schizophrenia. Psrohologioel Bulletin, 1958, 55, 316-327.

Mowrer, O.X. Peychotheraby, whoom and liaseareh. Naw York: Ronela, 1953.

Paecal, G.R. and Bweneen, C. Jearning in mentally 111 patients under conditiona of unusual motivation. Jourual of Pexconal167, 1952, 21, 240-249. 
Payne, H. H. Cognitive abnormalitiea. Hendbook of Abnermal Parebology.

In H.J. Eyeenok (Bd,). London, P1tman, 1960 .

Payne, R. At. An object classiflcation tests as a messure or overinclusive think lag in achlzophrente patiente. Britioh Journal of Soelal and Clinteal Pazchelosz, 1962. 1. $213-221$.

Pibhkin, V., Smlth, T.E. and Lundy, R*h. Verbal concept Ident1floation with chisophrenics and psyohopaths. Journal of Clinteal Fsychelosx, 1962, 18, 198-203.

Renmen, S., Cohen, S., Ditman, K.S, and krantz, J.R. Prychochesotherapy. Los Angeles: Weotern Medicel Pubileations, 1962.

Roberteon, J.P.S. The operant conditioning of speech and drawing behavior of ohronio schizophrentes. Zaltschrlft Bur Pareboloste Anvend, 1958, 12, 309-315.

Ronanow, C.V. Anxlety level and go lnvolvement as faetora in concept forration. Journel of Experimental Esycholost. 1958, 56, 266-172.

Rosenbeun, E*, Griasoli, J.L. and Meckovey, W.R. The relationchlp of age and privilege tatus to reaction tile Indioes of sehizophrenle motivation. Joumel of Abnormal and Soctel feycholon, 1957, 25, 202-207.

Se1gel,8. Lenperametrlo Btatistich. New York: MoGraw-H111, 1956.

Glegran. A.N. The effect of manlfest anxloty on a conoept formation task, a non-directed learning task and on tired and untined intelligence toots. Journel of Connulting Paychology, 1956, 20, 176-178.

spence. K.W. A thoory of enotionally based drive (D) and ita relation to performanoe in eimple learning situations. American Paycholokist, 1950, 13, 131-141.

Bpence, K. . and Farbor, I.Z. Conditioning of extinetion as a runction of anxiety. Journal of Experimental Psycholosi. 1953. 45. $316-119$.

Spence, K. W. and spenee, J.T. Sex and anxiety in eyelld conditioning. Esychologleal Bullotin, 1906, 65, 137-142. 
Spence, K.W. end Faylor, J.A. Mnxlety and strength of the UOS as deterainers of the amount of oyelid conditioning. Journal of ix erimental Pexchology, 1951, 42, 183-180.

Bpence, K. W. and laylor, J.A. The relation of conditloned response strength to anxiety in noral, neurotic and paychotic aubjects. Journal of ixperimental Earcholodx. 1953. 45. $265-272$.

Sweetland, A, and Chllde-ruay, L. The arfect of arotionallty on concopt formation. Jourael of Gameral Paychology. 1958. 29. $211-219$.

Taylor. J.A. A personallty soale of manfest anxiety. Journal of Abnorat and Soolal paxcholork. 1953, 48. 285-290.

Taylor, J.A. The effects of anxiety level and paychologioal stress on verbal conditioning. Journal of Abnornal and Soclal Psycholohy. $1958,52.55-60$.

Faylor, J.A. and spence, to performance in serial learning. Joumal of Experiaental Expholory, 1953, 44, 61-64.

Venables, P.H. Input ayafunction in achizophrenia. In B.A. (Ex.), Propress in Experimental Perconall ty Research. Volune T. hev hork: Academic. 1964.

Venableg, F.H. Paychophyolological aspects of echlzophrenla. Bret1 gh Journal of Medloal Poychologx, 1966, 39, 289-297.

Venablas, P.H. and lins. J.K. Laval of arousal and the subelaselfication of sehisophronia. Arohtves of General perchtatry, 1962, 2, 114-119. 


\section{VITA}

Nane: Donald Bdward Fuhrmann

Address: 2050 Sunat Trail, Riverwoods, Deereleld, I111nolo pate of B1rth: February 9,1937

Place of B1rth: Englewood, New Jerbey

Marital Status: Married, one chlla

Leademic Backround

Wesleyan University, Middletown, Connectiout

B.A.

Northwestern University, Bvanston, I111no1s $1962-63$

A.A. Loyola University, Chlcago, Illinols

$1963-67$

Loyola Univera1ty, Ch1eago, ILI1nole

$1967-68$

\section{3xpertence}

Clinical Peychologiet, Panily Paychothexapy Unit, OutRatient Department, Forest Hospltal, Des Plaines, I111nois. 1967 to present.

Staff Peychologist, Northwestern University Medical School Borvice, Ilinols state paychiatric Institute. Chicazo, Illinois. 1966 to present.

Clinical Research Paychology Tralnee, Illinols State Psychiatric Inetitute, Chicago, Ill1nols. 1965-66.

Paychology Intern, Illinols state Psychitaric Institute, Ch1cago, I111nois. 1964-65. 
Peychology Clerk, Ioyola University Ohila Guidance Center, Chicaso, Mlinois. 1964.

Resecrch Assistant, Garrett Theoloblcal Seminary, Evanaton, Illino1s: $1962-63$.

Bublications

Fubmann, D. E. The efrects of drive and ego-1nvolving Instruetions upon verbel bohavioz duriag delayed auditory feedbsck. Master's theals, Loyols Univer61ty. 1967 .

Honors and Nenbershipe

Dean's Llst, Wealeyan University, 1960. officor, Phi Nu Thete, Wesleyan Univers1ty, 1954-57. Pal Ch1, Loyola tiniversity, 1964.

Nember, Illnols Psychological Association, 1966. Meabex. I111nols Group Fayohotherapy Boolet3. 1967. Menber. Hidwest Peyohological Association, 1967. Meaber, American Psychological Association, 1968. 


\section{APPROVAL SHEET}

The dissertation submitted by Donald Edward Fuhrmann has been read and approved by members of the Department of Psychology.

The final copies have been examined by the director of the dissertation and the signature which appears below verifles the fact that any necessary chenges have been incorporated and that the dissertation is now given final approval with reference to content and form.

The dissertation is therefore accepted in partial fulfulment of the requirements for the degree of Doctor of Phllosophy. 